\title{
The Ramsdens and the Public Realm in Huddersfield, 1671-1920
}

\author{
DAVID GRIFFITHS
}

\section{Introduction}

TO A WELL-INFORMED visitor standing at Huddersfield's market cross today, a century after the Ramsdens sold their Huddersfield estate, their impact on the townscape remains inescapable. The market cross itself, topped by the family arms, records the grant of market rights to John Ramsden (later the first baronet) in 1671. The four streets which meet there, Kirkgate, Westgate, New St and John William St, were named by the Ramsdens, and the last two were their creation. With New St, dating from about 1770, they initiated a small street grid to the south, dominated by the Ramsden-built Cloth Hall of 1765/6; from there the axis of Cloth Hall St and the early nineteenth century King St ran east to Aspley Basin, the terminal port of Sir John Ramsden's Canal (1775-80). John William St, named after the fifth baronet, opened up a new Victorian grid to the north, with the Palladian railway station (1846-51) as its dominant feature. To the south of the cross is the handsome Georgian row of the Brick Buildings and to the north Waverley Chambers, one of three Queen Anne style office buildings along Byram St (named after the family seat near Pontefract); all four were built by the Ramsden estate as commercial developments. There is, then, a great deal of surviving evidence that in the eighteenth and nineteenth centuries Huddersfield was a 'Ramsden town'.

Such was certainly the claim of the Ramsden estate at the time. In their petition in 1774 for the Canal Act, the trustees of Sir John Ramsden, the fourth baronet (1755-1839) asserted that he was 'the owner of the whole town (except for one house) and of a considerable part of the lands adjoining'. In 1832 the parliamentary boundary commissioners, as they drew up new constituencies under the 'Great Reform Act', noted that 'every house but one in the Town belongs to the same proprietor'. ${ }^{2}$ Even after the incorporation 
of Huddersfield as a municipal borough in 1868, Sir John William Ramsden continued to assert that 'the Town of Huddersfield is almost entirely built upon portions of his estates', and successive Huddersfield Corporation Acts down to 1897 continued to reserve his rights as lord of the manor.

The estate's own claims have often been echoed in the national historiography. In his comparative study, Lords and Landlords, David Cannadine suggested that Huddersfield was unique in England in having 'one family in such a position of predominant territorial power'; that the small, single-member 1832 constituency 'amounted initially to a nomination borough'; and that 'local government remained almost entirely in their hands until the passing of the Huddersfield Improvement Act in 1848, ${ }^{3}$ Similarly, Norman Gash claimed that Huddersfield, 'without coming quite into the category of proprietary boroughs ... was sufficiently under the control of ... Sir John Ramsden to defy the efforts of radicals and tories to capture the seat'. ${ }^{4}$

Scholars who have undertaken more detailed local studies have been a little more sceptical.Jane Springett, in her extensive work on land ownership, concluded that 'Contrary to the opinions of many contemporary observers, the Ramsden estate did not at any time enjoy an absolute monopoly in land'. ${ }^{5}$ Similarly, Vivienne Hemingway found 'little evidence that Huddersfield was a nomination borough in the hands of the Ramsden family', though that did not mean that early parliamentary elections were free of undue pressure or corrupt practices. ${ }^{6}$

This chapter will assess the Ramsden influence on the public realm of the town. It will identify a succession of periods characterised by different relationships between the estate and the town, and the turning points between these.Within each period, attention will be given to three dimensions: the extent and location of Ramsden land ownership; the institutions of town governance; and the development of public facilities and the role played by the estate in their development, whether directly or through the governing institutions.

\section{The long eighteenth century: developmental fits and starts}

In acquiring the town's market rights in 1671, it has been said,'John Ramsden may have been looking to the long-term development of the town as a trading centre', as well as securing a new source of income for the estate. ${ }^{8}$ If so, it was indeed a long-term ambition: it would be the best part of a century before the estate took further initiatives towards economic development and urban planning. During this period, the town remained tiny by later standards - the estimated township population increasing from about 1,000 in 1716 to 3,000 in $1778^{9}$ - and the estate took little interest in the facilities it offered. 
THE EXTENT OF THE ESTATE

The claimed ownership of 'all but one house' takes a popular if apocryphal form in a tale related by generations of local historians, and appearing in many versions. The house in question was owned by one Thomas Firth, and the local historian, G. W. Tomlinson, set the tale down thus:

It would be impossible to speak of Mr [Thomas] Firth without allusion to his sharp, practical shrewdness spiced with a flavour of wit. The story about the cottage at the low side of the church-yard which belonged to him is a case in point. The site of this cottage was the only bit of freehold in the middle of the town which did not belong to the Ramsden estate. The ground was wanted for some improvements, and it is said Sir John offered to cover the land with sovereigns if he might have it. Mr Firth replied, 'Put them edgeways, Sir John and the land is thine. ${ }^{10}$

A Firth biographer describes the story as 'celebrated and not authenticated', though true to Firth's character. ${ }^{11}$ It certainly needs to be contextualised.

The name 'Huddersfield' in the eighteenth and nineteenth centuries could denote any of three nested geographies. The parish of Huddersfield extended for a dozen miles along the north bank of the River Colne, from Marsden in the west to Bradley in the east, comprising seven townships. One of these was Huddersfield township, which also became the parliamentary borough in 1832. This extended several miles from today's town centre, particularly northeastwards, and was further divided into five hamlets, one named Huddersfield. Even this smallest 'Huddersfield' was far from fully urban - Huddersfield being described as being a 'miserable village' in the late eighteenth century. ${ }^{12}$

By then the Ramsden estate was undoubtedly dominant within the inner hamlet - 'the middle of the town'- and the 1786 enclosure award allocated 286 of 323 acres of common land to Sir John. ${ }^{13}$ However, two maps of that period, and land tax returns, reveal the holdings of other substantial freeholders close to the centre, notably those of the Bradleys at Newhouse (Highfields), William Walker at Bay Hall, Sir John Lister Kaye at Greenhead/ Gledholt/Springwood and the scattered Hirst \& Kennet estates. ${ }^{14}$ Although these largely came to market in the early nineteenth century - Kaye's estate in 1804, the Hirst \& Kennet estates in 1819, Bradley's in 1820 - none fell to the Ramsdens until mid-century [see p. 58].

Further from the centre were other more substantial landowners. Within the township were the Pilkingtons at Bradley, Whitacres at Deighton and Thornhills at Sheepridge, the last also dominant in Lindley township. Across the river were the extensive Kaye estates at Dalton and those of the Lockwood Proprietors in that township. It remains undeniable, however, that 
in the central area where Huddersfield's urban public realm developed, the Ramsden estate was overwhelmingly the dominant landowner.

\section{GOVERNANCE: THE ANCIEN REGIME}

Until 1820, the town was governed by the typical English triad of manor, parish and county magistrates. The estate's direct role was thus through the civil and minor criminal jurisdiction of the manorial court leet. This met at Almondbury at least annually to appoint its traditional officers, including the constable, who was 'head of the town', and to prosecute a range of nuisances. A dozen or more jurors, recruited from the gentlemen and 'middling sort' of the town, were convened by the estate steward, invariably a local lawyer.

It seems unlikely that successive lords of the manor took much interest in this low-level regulatory activity. They did, however, have other channels of influence at their disposal. The parish vestry retained its Elizabethan jurisdiction over highways and the poor law, and the Ramsdens had held the nomination rights to the parish church, St Peter's, since 1546; the vicar, in turn, had the right to appoint one of two churchwardens, whose duties had a significant secular dimension. I have found no evidence of the Ramsdens seeking direct influence in the affairs of the vestry.

At a higher level again, as major landowners the Ramsdens were of course well-connected in county society. Their acquisition of Byram around 1632 was partly prompted by its proximity and ready access to York, and from the eighteenth century successive links by marriage to the Earls Fitzwilliam, often Lords Lieutenant of the West Riding, would have afforded opportunities to influence the appointment of magistrates to the county bench and thus to the Huddersfield petty sessions. There is certainly evidence of such influence being exercised by the fifth baronet later in the nineteenth century ${ }^{15}$ and the opportunity would have been available long before that. The magistrates had the oversight of all local matters, including appointments by the vestry of highways and poor law officials, and would have been an obvious focus for the exercise of influence.

\section{THE ESTATE AND ECONOMIC DEVELOPMENT}

With these territorial and institutional powers at their disposal, what part did the estate take in this period in the development of the town's economic infrastructure and social facilities? For a century after they had acquired the market rights, the answer is only a very small part.

Two exceptions should be mentioned. In 1681 land was given for a grammar school at Seed Hill (near Shore Head), which had 20 pupils in 1743, although by 1819 it had been 'allowed to deteriorate into an elementary school of the 
National [i.e.Anglican] type'. ${ }^{16}$ In 1743 a waterworks was established: water was extracted from the river at Engine Bridge and pumped to a small reservoir at the top of the town, whence it was made available to the town through wooden pipes. The water was of course unfiltered - though the river was no doubt much cleaner than it would be a century later - and the pipes such that on one occasion they were reportedly blocked by a large trout. ${ }^{17}$

The turn towards economic development came in the early 1760s, late in the life of Sir John Ramsden (1698-1769), third baronet. He it was who decided to build the Cloth Hall, a principal feature of the town from its opening in 1766, through enlargements in 1780 and 1864, to its demolition in 1930. It provided a covered market for cloth in place of open stalls in and around the Market Place and parish churchyard. Its economic significance has been summarised thus:

The Cloth Hall made Huddersfield a mart where business was done not only in wool and cloth, but in all that related to them; and it was done at inns, or up inn-yards, at street corners and in warehouses, as well as at the Cloth Hall. Nor is that all. A market town develops the mercantile side in place of the manufacturing, and it becomes a centre for allied and subsidiary trades. So banks and warehouses clustered around the Cloth Hall ... all the many dressing shops and dyehouses were concentrated in the town, and it was the headquarters of the packers and the carriers, by waggon or canal, as well. ${ }^{18}$

When the Cloth Hall opened there was no canal, and carriage was perforce by waggon. During his last decade, Sir John supported the fast-developing network of turnpike roads. In 1759 he invested $\mathcal{S}^{3} 300$ in the Wakefield to Austerlands (near Oldham) turnpike; in 1765 he became a trustee of the Birstall to Huddersfield trust (towards Leeds); and in 1768 of the Huddersfield to Woodhead turnpike (towards Sheffield). 'Five turnpike roads converged in Huddersfield within the decade after 1759 suggesting that in the West Riding cloth producing region it had entered the same "league" as Halifax, Wakefield and Bradford'. ${ }^{19}$

During that decade, too, in 1766 the first survey was undertaken for Sir John Ramsden's Canal, and this vital link to the Aire \& Calder Navigation, and thence to the North Sea, was constructed between 1774 and 1780. After the initial survey, work was not taken forward before Sir John's death in 1769, when the fourth baronet was only 13 years old. Until 1776, however, estate management was under the management of his 'conscientious' uncle and trustee, Thomas Ramsden ${ }^{20}$, who resurveyed the line in 1773 and obtained the necessary legislation in 1774. Land acquisition and construction cost some £11,500. As Dennis Whomsley commented, citing contemporary sources, 


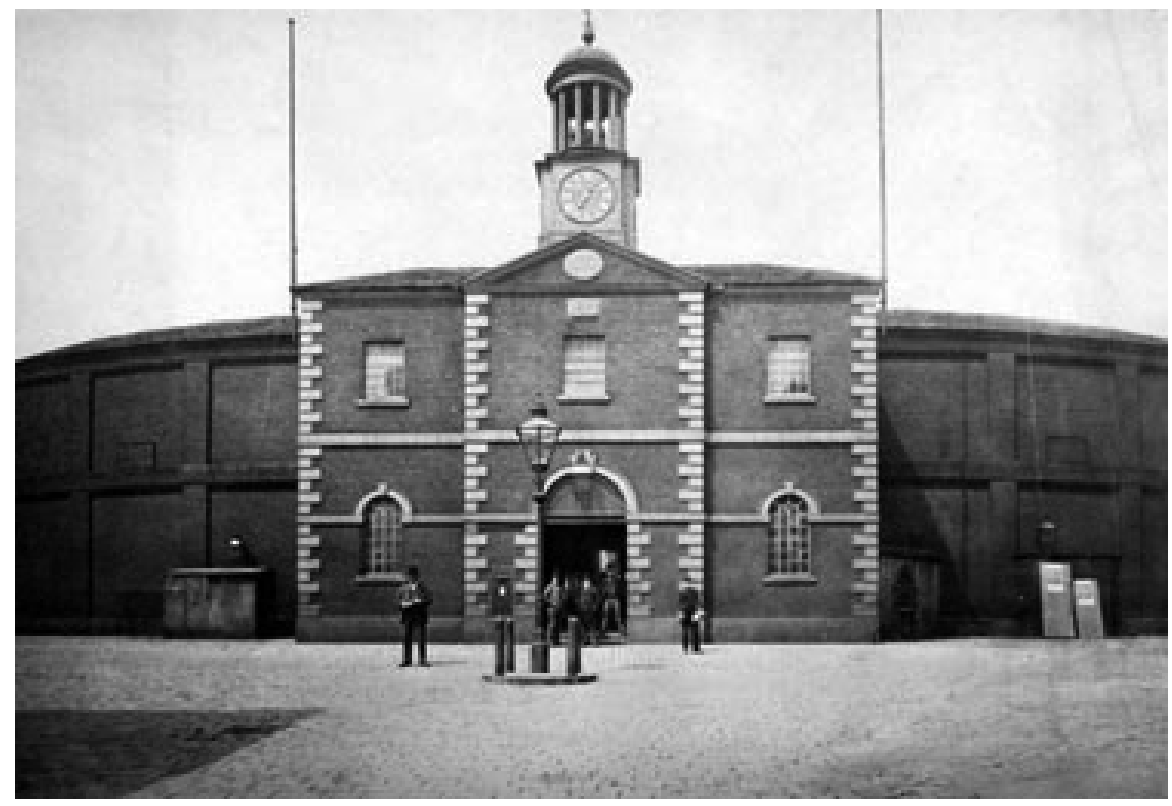

17. Cloth Hall, erected 1766 and enlarged in 1780 and 1864.

Kirklees Image Archive

this was a remarkably small price to pay for putting the town on a main water highway to Hull 'and all its associated rivers and canals', and being 'the principal means of raising ... Huddersfield to be one of the principal marts for woollen goods in the West Riding'. ${ }^{21}$

It was also a revenue-earning venture for the estate, which erected canal warehouses and stood to gain from the tolls paid by carriers. These were limited by the Act to a 6 per cent return on the capital laid out, and the turnpikes to less but, as Whomsley emphasised, if 'the new means of transport in themselves were not so valuable as capital investments, yet they vastly increased the value of the estate. ${ }^{, 2}$ The estate always did best when it recognised local developmental needs and its own interests were aligned, not in tension.

The fourth baronet came of age in 1776. Surveys of the town and wider estate were made in 1778 and 1780 by William Whitelock, a Ramsden tenant who was soon to be appointed a Huddersfield enclosure commissioner. As noted above, the 1789 enclosure award allocated nearly 90 percent of the newly enclosed land to the estate. It also provided 50 new roads, five quarries for their repair and five public wells. Whomsley suggests that these events should all be seen as 'part of the planned development of the estate to take the fullest advantage of the building of the canal ... The plan probably originated with 


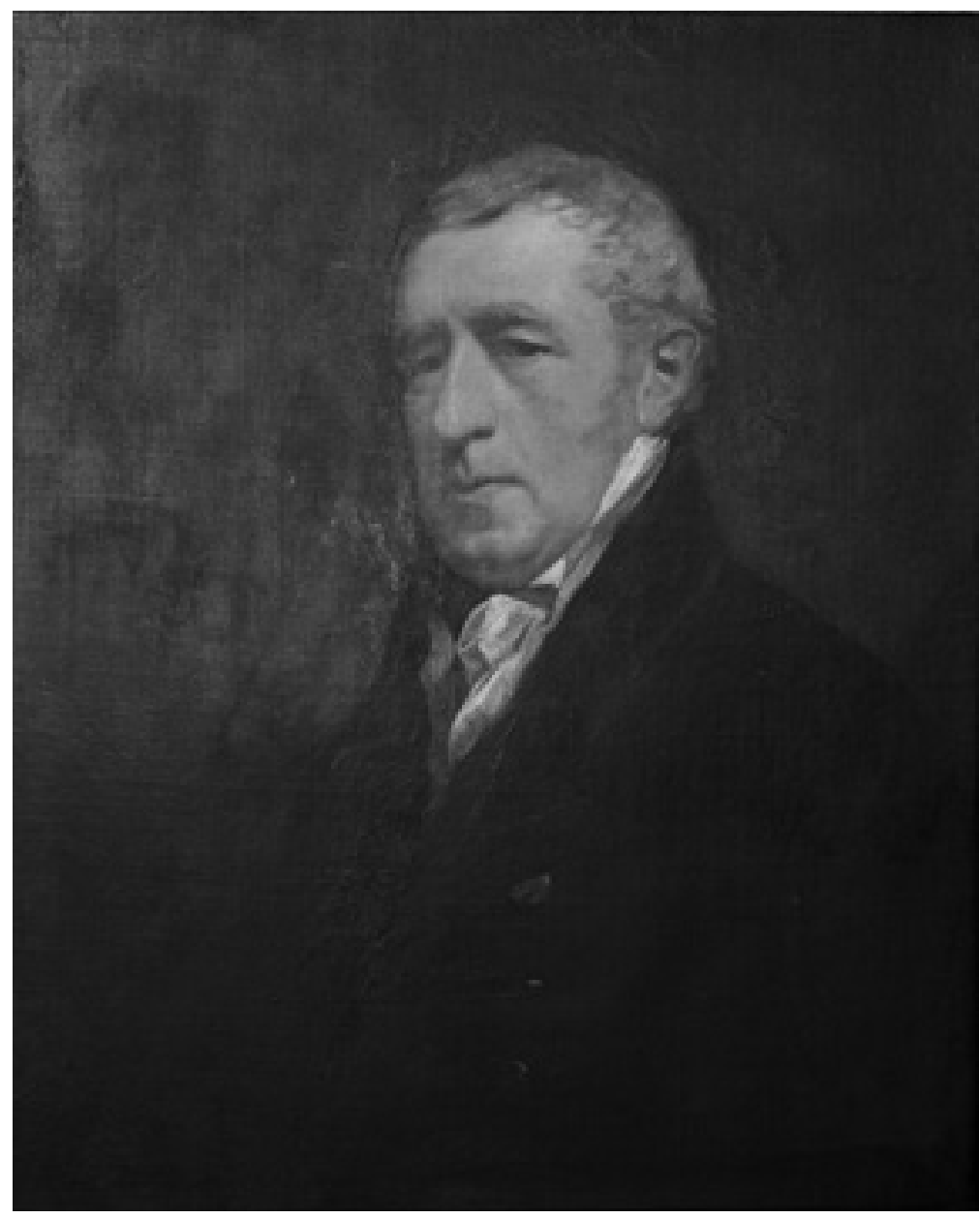

18. Sir John Ramsden, 4th Bt (1755-1839).

Muncaster Castle

the third baronet, it almost certainly was executed by his experienced brother Thomas'. ${ }^{23}$ If he is right - documentary evidence is lacking - then this should be judged a significant contribution by the estate to the public realm.

The 1789 Act's new roads were on open land, but the development of the first town centre grid was soon to follow. This comprised New St, Cloth Hall St and King St, all apparently laid out between about 1797 and 1807. ${ }^{24}$ As well as town houses, the development included the Brick Buildings on New St, with accommodation above shops, and the expansion and relocation of a butchers' shambles and slaughterhouse, first established by the estate around 


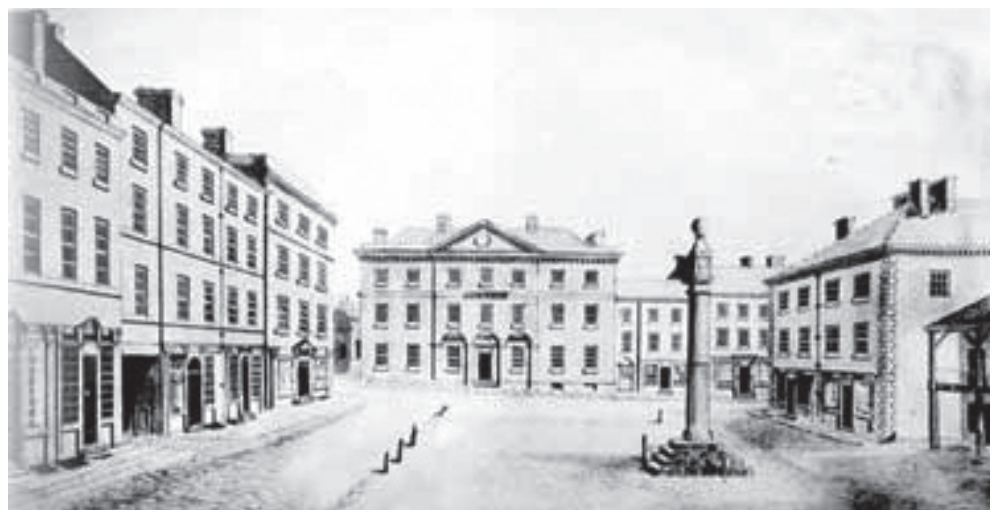

19. Market Place, looking towards Kirkgate/Westgate, with the old George Inn (centre). Kirklees Image Archive

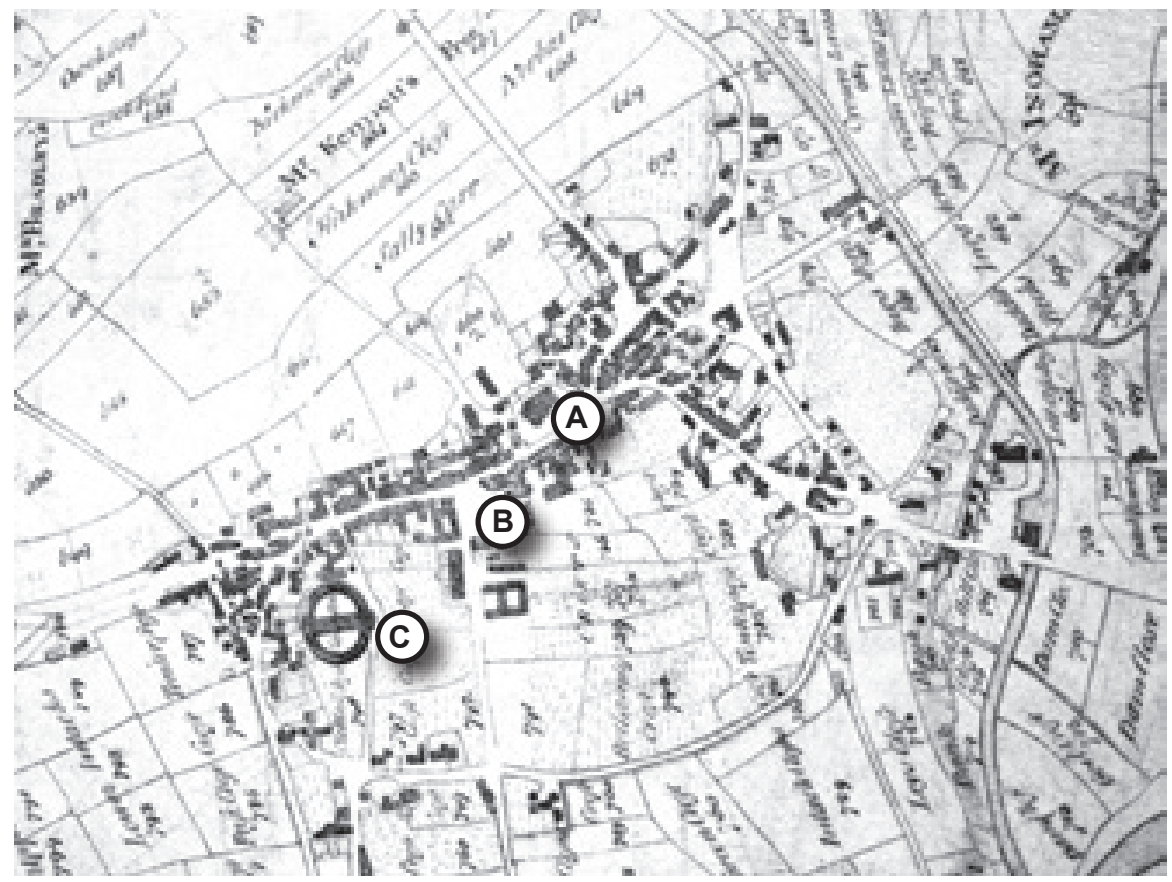

20. Ramsden estate map (1778) - town centre street map of Georgian Huddersfield.

At this time Huddersfield was virtually a one-street town extending along the line of the modern Westgate and Kirkgate. The Parish Church (A) and the Market Place (B) are central and the new Cloth Hall $(\mathrm{C})$ prominent to the left.

West Yorkshire Archive Service, Kirklees 


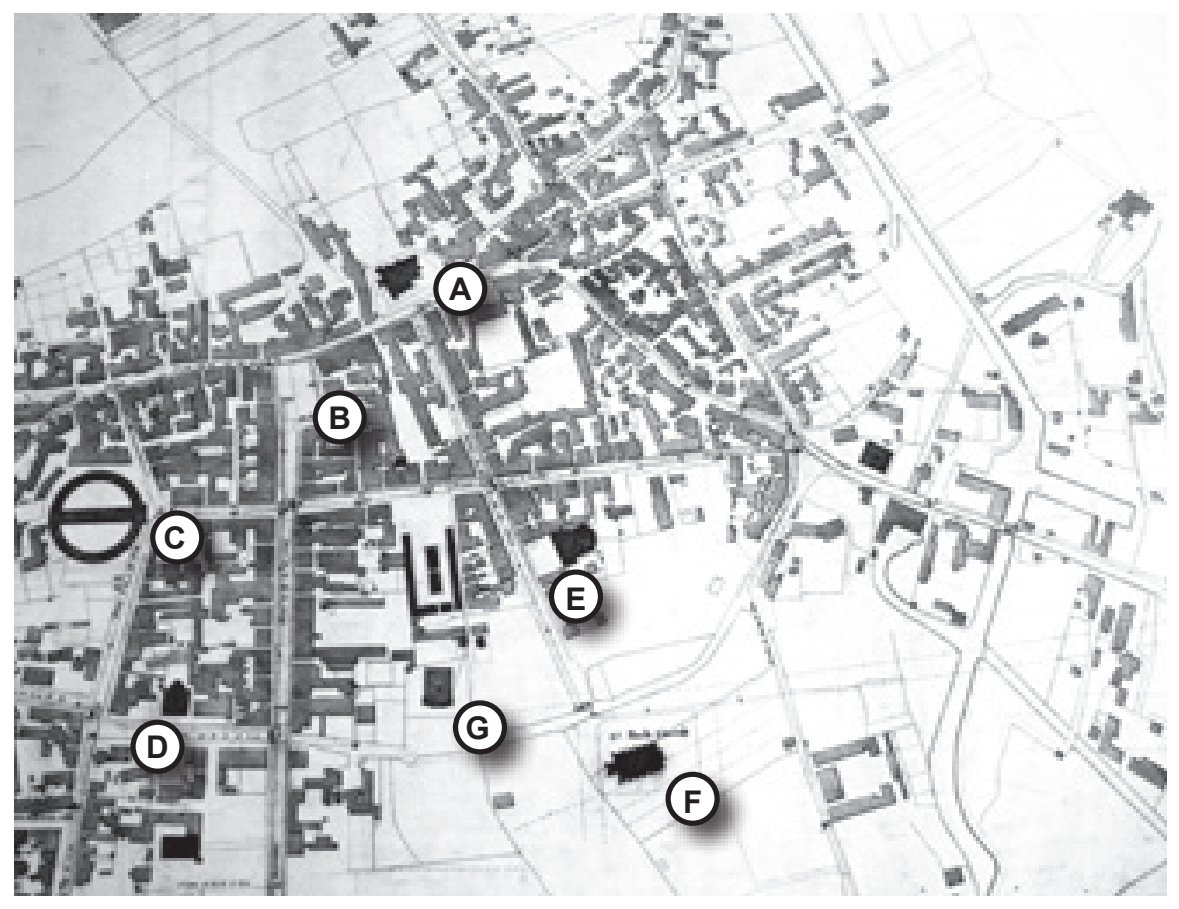

21. Thomas Dinsley map (1828) for the Waterworks Commissioners, showing the laterGeorgian street pattern.

The town has now extended to the south of the original development, past the Cloth Hall (C), along Market Street to beyond High Street with its Methodist New Connexion chapel (1815) (D); from the Market Place (B) along New Street, past the Brick Buildings on the west side to beyond King Street; and from the Parish Church (A) along Cross Church Street to Queen Street, with its Wesleyan chapel (1819) (E) and thence to the isolated St Paul's church (1829) (F). Skirting the southern part of the map, Ramsden Street, with its Congregational chapel (1824) $(G)$ is scarcely developed. The building to the north of the chapel was the Shambles.

West Yorkshire Archive Service, Kirklees

1770 south of the Market Place. With an additional axis along Queen St/ Cross Church St, this first grid would continue to develop on Ramsdenleased plots until about 1825, forming a Georgian townscape which partly survives today. ${ }^{25}$

In summary, little was to happen for 80 years after the grant of market rights, but the half-century from 1765 was characterised by a vigorous approach to the development of economic infrastructure and the creation of a small Georgian town centre. This was achieved on the basis of a relatively stable stock of land, and without any formal involvement in town governance beyond the traditional rights of the lord of the manor. 


\section{Early $19^{\text {th }}$ century passivity}

The next period, from the 1810s until the mid-1840s, was to be quite different, with the estate taking a much more passive approach, to the point of neglect, while urban conditions moved towards crisis point. This was down to the personalities and capabilities of the lord of the manor and his agents. The fourth baronet had deferred to his uncle Thomas's leadership of estate affairs even after coming of age in $1776 .{ }^{26}$ Although lord of the manor for over 60 of his adult years until his death in 1839 , Sir John visited the town only once, in 1822. This neglect need not have been decisive had he been well-served by his agents after Thomas's death in 1791. To begin with he relied on his father's steward, John Crowder, who had worked closely with Thomas Ramsden, ${ }^{27}$ but Crowder died in 1816 and was replaced by John Bower, and this was perhaps the real turning point.

Based at Smeathalls, close to Byram, Bower was not a full-time Ramsden employee but undertook other surveying work, for example as an enclosure commissioner ${ }^{28}$ He was the Huddersfield agent until his death in 1844, five years after Sir John's, but notoriously only visited the town twice a year to collect the rents, and took a laissez-faire attitude to what was built on the estate's lands. While the township population grew by over 80 percent between 1801 and 1821 , from 7,268 to 13,284 , and by a further 89 percent to 25,068 by 1841 , the estate's 'entrepreneurial activity during the period of Huddersfield's most rapid growth was limited solely to the provision of wide main streets' ${ }^{29}$ These therefore came to be surrounded by warrens of insanitary and overcrowded premises, largely held on ill-defined 'tenancies at will'. ${ }^{30}$ In the year Bower died, the resulting conditions were famously described thus by the Chartist activist and journalist, Joshua Hobson:

... there are whole streets in the town, and many courts and alleys, which are neither flagged, paved, sewered nor drained; where garbage and filth of every description are let on the surface to ferment and rot; where pools of stagnant water are almost constant; where the dwellings adjoining are thus necessarily caused to be of an inferior and even filthy description; where disease is engendered, and the health of the whole Town endangered. ${ }^{31}$

This contrasts with Friedrich Engels' superficial observation of the main streets in 1845 [see p. 55].

INNOVATIONS IN GOVERNANCE ${ }^{32}$

There had nonetheless been a modest institutional response to the deteriorating urban conditions. To the traditional institutions were added, 
in 1820, the Commissioners of Lighting, Watching \& Cleansing (CLWC). Established by Act of Parliament, their eponymous responsibilities ran only 1200 yards from the market cross, within the township of Huddersfield which radius included portions of Fartown and Marsh hamlets as well as Huddersfield itself. For this small tract, the Act named 59 Commissioners to act, including Sir John Ramsden, his four sons and John Bower.Vacancies were to be filled by co-option, subject to Sir John's approval. Presumably he therefore had the right of veto over the initial appointments too, so the CLWC could have been shaped as an instrument of Ramsden control over urban management. In practice this opportunity was not taken. No Ramsden, nor Bower, ever attended a CLWC meeting. Two other men sometimes described as Ramsden agents, Bradley Clay (a canal agent) and James Booth, were active early Commissioners, and Sir John took their advice in filling vacancies in 1823 (which happened only twice in 28 years), but there is no evidence in the minutes of any active relationship between the CLWC and the estate. ${ }^{33}$ Moreover, the court leet continued to operate in parallel, notably in January 1832 when, at the height of the first cholera epidemic, 22 cases of sanitary infractions were prosecuted. ${ }^{34}$

In 1827 the Huddersfield Waterworks Commissioners (HWC) were established, with a constitution closely modelled on the CLWC although this time with 120 Commissioners, including five Ramsdens and up to four of their local and canal agents. Its genesis is considered further below.

These bodies existed on Ramsden sufferance. From the late 1820s, however, Huddersfield began to regain the reputation for radical politics which it had earned at the time of the Luddite uprising and its after-shocks in the 1810s. It eschewed the opportunity to establish an oligarchical select vestry under the 1819 Sturges Bourne legislation, resolving to retain an open vestry through which the views the town could be expressed. Those views would soon embrace the campaigns for the limitation of factory hours, for a wider male suffrage and against the New Poor Law. ${ }^{35}$ By the mid-1830s a vigorous popular politics had developed in the vestry, which took the opportunity of the 1835 Highways Act to establish an elected Board of Highway Surveyors, soon to be a thorn in the side of the increasingly ineffective CLWC.

It was in this context that Huddersfield gained parliamentary representation for the first time in 1832. A petition for a two-member constituency, based on the parish rather than the township and therefore diluting Ramsden influence, was resisted by the family, with the eldest son, J. C. Ramsden, then MP for Malton (a Fitzwilliam-controlled seat), declining to present it to Parliament. In return the town resisted his declared intention to stand as Whig candidate, greeting him with a stormy reception, and he withdrew in favour of a local man Lewis Fenton, who defeated the Radical Joseph Wood 
by 263 to 152 in a riotous first election. ${ }^{36}$ This was despite Ramsden's quite 'advanced' Whig views: he had supported Parliamentary reform and resigned as a deputy lieutenant in 1819 in protest when Earl Fitzwilliam was dismissed from the lieutenancy for supporting an inquiry into the Peterloo massacre. On the other hand, he was for free trade and against the ten hours campaign, setting him against Huddersfield's radicals. ${ }^{37}$

These events illuminate the limits of Ramsden influence. As mentioned earlier, Hemingway's close local study of parliamentary politics led her to challenge Cannadine's judgement that Huddersfield was a 'nomination borough', and the spurning of Ramsden's candidacy bears this out. A similar point applies to local government. Katrina Navickas has argued that 'In many of the towns and villages in Lancashire and the West Riding that were dominated by one or two master manufacturers or major landowners, such as Halifax and Huddersfield, it was much harder for oppositional groups to gain a foothold in local government. ${ }^{38}$ In fact Radicals and Liberals in Huddersfield made good use of the machinery of the vestry to challenge the CLWC on sanitary issues and on the control of policing. ${ }^{39}$

\section{LAND OWNERSHIP IN STASIS}

If the estate was failing to manage the land it held, neither was there any drive to expand its holdings. Although Sir John left behind the youthful indiscretions alluded to by Whomsley, he preferred to invest in major enhancements of the house and park at Byram rather than in income-earning assets elsewhere. As noted above, the estate took little or no advantage of the release of several freehold estates in the town around 1820. By 1844, the Huddersfield estate amounted to 1,213 acres, or 30.7 percent of the township by area. ${ }^{40}$

When Sir John Ramsden died in 1839, his eldest son having pre-deceased him, the estate passed to the trustees of his grandson, the fifth baronet, John William Ramsden, who was then only seven years old. The deceased's will put substantial obstacles in the way of the development of the estate. Most of it was to be held in trust for his heirs, rather than being freely disposable to meet changing needs for land. This was not unusual in itself: as has been said, 'In the early nineteenth century the English land system was oriented towards the preservation of dynasties and dynastic dependents, not towards the efficient exploitation of the land'; ${ }^{41}$ still less of course towards public benefit. The fourth baronet's will further provided, however, that expenditure was to be limited to accumulated surplus income and that proceeds of any land sales had to be reinvested in land, and restricted the terms of lease which the estate could offer. ${ }^{42}$ Distinctions between the 'settled' and 'devised' estates added further complexity. ${ }^{43}$ As we shall see, these inflexibilities would take some unravelling. 
Nonetheless this period, and particularly the decade or so from 1827, did see a significant extension of the town's urban facilities. The new waterworks of 1828 was quickly followed by the Infirmary, which opened in 1831 and, in 1837-8, by the Guild Hall and Philosophical Hall. The former became home to the county magistrates, the latter included a news room and lending library, and both offered large halls for public meetings and other events. These were among the buildings which led Engels to salute Huddersfield as 'the handsomest by far' of the Pennine factory towns. ${ }^{44}$ Together with the town and county police stations and lockups, and later county court building, they formed a rudimentary civic quarter around Ramsden St. ${ }^{45}$ But these were all independent initiatives: the estate was not involved. Moreover, it sometimes actively resisted initiatives from other actors. Two examples concern water supplies in the 1820 s and railway proposals in the 1840 s.

The pumped water supply from the river had become wholly inadequate to the town's needs. In 1826, 74 inhabitants petitioned Sir John 'that an abundant and never failing supply of pure water might be obtained and conveyed to the town at a moderate expense'. They proposed to activate a scheme, drawn up as long ago as 1819 , to capture spring water from Longwood, to raise the necessary capital and to manage it as a not-for-profit utility. ${ }^{46}$ The result was the Waterworks Act of 1827 and creation of the first Longwood Reservoir, with water piped to a service tank at Spring St close to that of the previous scheme (and fronted by the 'handsome' Waterworks Office, which survives today). The estate acceded to the plan, but only after insisting that the HWC should buy the old waterworks and make an annual payment of $\mathcal{1} 100$ for access to the streets to lay mains. Thirty years later, Ramsden rejected a strong request to waive this payment, which continued until $1868 .{ }^{47}$

The second example was the estate's attitude to the railway. ${ }^{48}$ As industrialisation gathered pace, the Lancashire \& Yorkshire Railway had opened its Calder Valley line in 1838, linking Manchester and Leeds but bypassing Huddersfield. In 1843 the company proposed a branch from Cooper Bridge, terminating at Aspley. This was opposed from two angles. Bower advised the Ramsden trustees to resist the branch as a threat to their canal revenues, and the trustees concurred in January 1844. By this time the limitation to a 6 per cent return on investment was neglected and the estate's exploitation of its monopoly of eastward transport had become a bone of contention, the celebrated factory hours and Poor Law campaigner, Richard Oastler, taking up the issue in $1834 .{ }^{49}$ Moreover, strong voices in the town were insulted that Huddersfield should be placed on a railway cul-de-sac. A 
petition was raised against the L \&Y proposal and a public meeting convened, from which estate steward, J. C. Fenton, reported on 23 February that:

the Huddersfield people are determined that they will have a railway $\ldots$ great numbers ... signed the petition with the intention of throwing out the obnoxious branch but in the expectation that an advantageous railway communication be brought forward without delay..$^{50}$

As the next section sets out, the railway issue would soon precipitate a major turning point in the estate's management, which returned to its earlier developmental activism. Its initial resistance to the coming of the railway, however, typified its position in the last decades of Sir John's and John Bower's lives. Land ownership had remained broadly stable. The estate had abdicated from development, made little use of institutions of governance potentially under its control, and had made no contribution - or even a negative contribution - to the fast-developing public realm beyond the layout and naming of streets.

\section{A decade of activism, 1844-55}

All this was to change in 1844, a major turning point for the estate and the town. With hindsight the moment seems strangely delayed. The trustees, who took office in 1839, led by Earl Fitzwilliam with J. C. Ramsden's widow, Isabella, the other leading figure, would transform the estate's policies. ${ }^{51}$ For another five years, however, until his death in 1844, Bower's advice seems to have held sway. Then came abrupt change with the trustees' appointment of George Loch as their principal agent, and his appointment of Alexander Hathorn as full-time Huddersfield agent.

Loch's father, James, was a celebrated estate manager employed by several leading landowners; indeed his name 'seems to have been a kind of household word in the highest circles of aristocracy' ${ }^{52}$ His positions included superintendent of the Bridgewater estate in the north-west, where his son George served as his deputy and Hathorn was also employed. In turning to Loch, therefore, the trustees were bringing in a manager of high pedigree.

George Loch spent the last week of May 1844 in Huddersfield, tramping the town, meeting key informants and recording what he found in a notebook. ${ }^{53} \mathrm{He}$ had been asked to examine canal and railway matters and tenure arrangements. He found strong support for direct railways, both EastWest and South via Sheffield to London. Leading business figures told him that the estate's canal-based opposition to the through railway had been a mistake, and that development was being held back by the lack of proper leaseholds. Visiting Bower's putative successor, the canal agent William Alderson, he 
found that his office 'smelt overpoweringly of snuff and spirits', and that the accounting system was 'very rude and imperfect'. Bower's visits to the town, he was told, had amounted to no more than two to three weeks each year. Within a week of the visit, Loch's conclusions and recommendations were encapsulated in a 21-page report to the trustees; they amounted to a complete reversal of three decades of neglect of the town's potential. ${ }^{54}$

As noted earlier, Whomsley suggested that Thomas Ramsden had pursued an integrated development strategy in the 1780s. Whether nor not that was the case, it is clear that Loch guided the trustees to such a strategy in the 1840s. Its components were tightly inter-connected across the three dimensions of ownership, governance and development.

\section{ECONOMIC DEVELOPMENT AND LAND OWNERSHIP}

The starting point was the reversal of policy on the railway. The estate abandoned its defence of canal revenues and any idea of a low-level branch line to Aspley. Instead it released land to make possible the high-level route - essential to through traffic - and the station on its present site, and sold the Ramsden Canal to the railway company, which had already bought the Narrow Canal. Trains first ran to Leeds in 1848, Manchester in 1849 and Sheffield in 1850 when the Palladian station building - a 'stately home with trains in' by noted York architect J. P. Pritchett - was completed. ${ }^{55}$ As well as energising economic development through much enhanced connectivity, these transactions brought $£ 87,000$ into the estate's coffers and provided new urban and financial opportunities.

In planning terms, the station provided a magnet for the extension of the town northwards from the historic axis of Westgate/Kirkgate. Over the next 30 years, on this formerly open land a new street grid was laid out. The 'Victorian new town', to the north of the Georgian grid, was a bold town planning scheme. To create an approach from the Market Place to the station, the George Inn was demolished to make way for John William Street. Today this leads into St George's Square, in front of the station, and is flanked by the replacement George Hotel which the trustees commissioned from William Wallen, and handsome warehouses erected under the guidance of their consulting architect, Sir William Tite who designed one of them, Tite's Buildings, directly for the estate. The Square did not feature in the estate's initial plans, which centred on 'the erection of new buildings such as woollen warehouses, shops and banking houses etc. etc. ... situated in front of the railway station'. ${ }^{56}$ But it was strongly advocated by the newly-established Improvement Commissioners [see p. 58], and especially by Joshua Hobson, by now their clerk. With Hathorn's eventual support, they were able to win 
over Loch and the trustees, and the result was one of the finest public spaces in the north of England. ${ }^{57}$

Financially, the proceeds of the railway sales also enabled the estate to embark on a programme of land acquisition which was to continue for the next 40 years. Within the first decade, acquisitions included several of the estates close to the town centre but not in Ramsden ownership - 40 acres at Bay Hall, beyond the station, in 1844/5; two portions of the former Bradley holdings at nearby Newhouse in 1845 and 1848; and 80 acres at Greenhead/ Gledholt, again in $1848 .^{58}$

But there was no point in acquiring new freeholds unless they could be profitably leased, and to do so it was necessary to remove some of the legal impediments arising from old Sir John's will. The 1844 Ramsden Estate Act allowed the estate to renew leases which had lapsed with his death; to create new leases of up to 60 years; and to allot lands on the devised estates for streets and other public purposes. ${ }^{59}$ Armed with these new powers (further extended by a second Act in 1848), the estate was able to respond to a vigorous demand for development land. Even before the 'new town' was approved by the trustees in 1849, another warehouse quarter was being laid out from 1846 around the Cloth Hall (the streets all bearing trustees' names - Dundas, Fox and Serjeantson). ${ }^{60}$ By 1849, in a review of progress, Loch was able to report to Mrs Ramsden that the town was prospering and much building was going forward. ${ }^{61}$ Perhaps responding to Hobson's 1844 report, moreover, the estate was exercising a good deal of control over the quality of development. As Springett explains, after Loch's arrival 'New back-to-back houses and cellar dwellings were forbidden, building lines enforced, and materials and building standards rigorously supervised. ${ }^{62}$

\section{A NEW GOVERNANCE SETTLEMENT}

By then, too, there had been a new institutional settlement. By the 1840s the established bodies were struggling, with endemic conflict between the CLWC and vestry, neither of which had the powers or personnel to address burgeoning urban problems. In neighbouring towns, the solution adopted in the late 1840s was to incorporate a municipal borough under the 1835 Municipal Corporations Act. In Huddersfield, after a petition for incorporation had failed in 1842, this seems not to have received serious consideration again for 15 years. Instead the Huddersfield Improvement Commissioners (HIC) were established, replacing both the CLWC and the vestry's Board of Surveyors, and acted as a quasi-municipal authority for the next 20 years. The HIC was brought into being by an apparently unlikely alliance of vestry activists, notably Hobson who became the HIC clerk of 


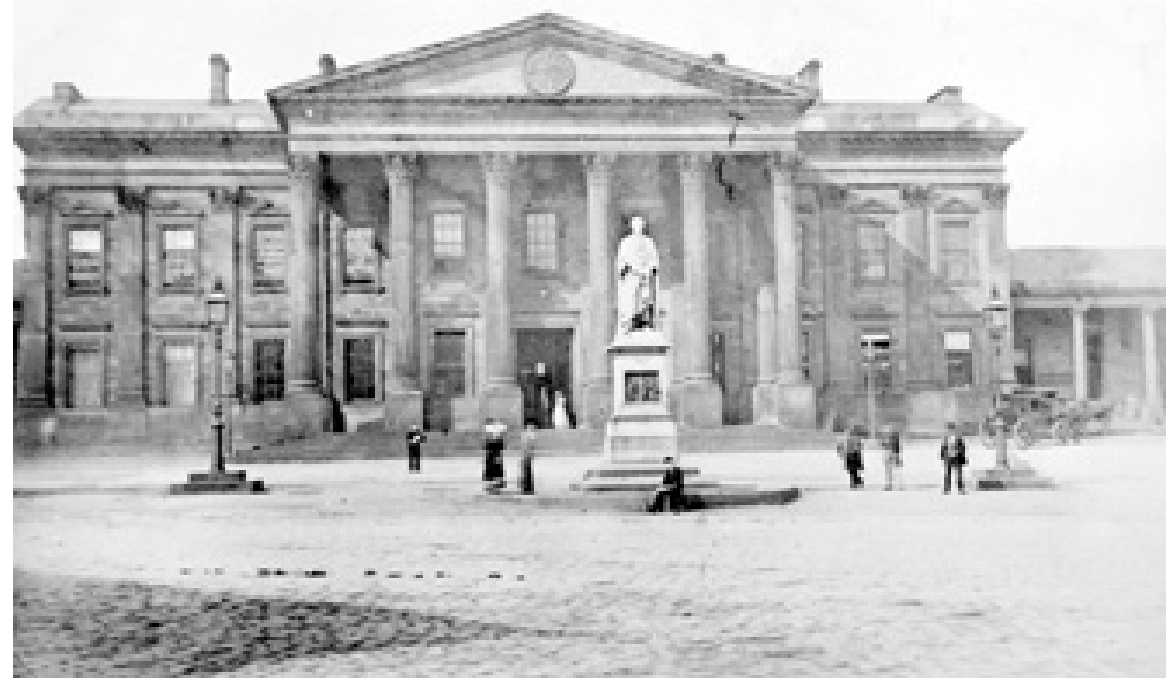

22. Railway Station (1846-51) by J. P. Pritchett, with the statue of Sir Robert Peel in the foreground (erected after 1873, removed 1949).

Kirklees Image Archive

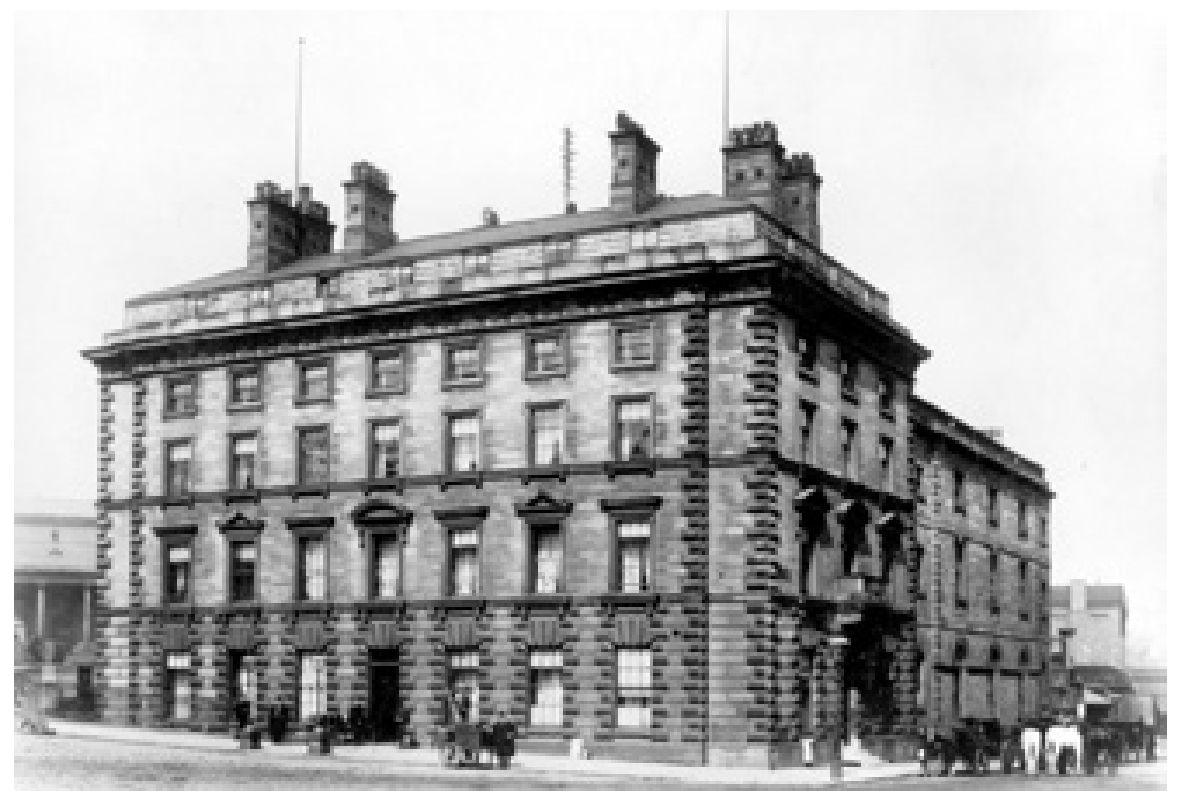

23. George Hotel (1848-1851), by William Wallen. The top floor, above the parapet, is a later addition.

Kirklees Image Archive 
works; the local magistrates and other 'principal inhabitants'; and Loch and Hathorn, supported by the trustees. ${ }^{63}$

Loch may well have taken a broad view of the mid-century needs of the town and the inadequacy of the earlier bodies. However, the estate also had a more specific interest in supporting the HIC settlement. Another term of Sir John's will had been the provision of $£ 20,000$ to be spent on 'improvements' to the estate, and a further $£ 25,000$ was now allowed under the 1848 Ramsden Estate Act. But the intention of these arrangements was disputed and would remain a bone of contention for decades ahead, both within the estate and with the town. As Loch pointed out in his 1849 progress report, this had stood in the way of the continued creation of new streets with paving and drainage. However, this 'great difficulty that has always opposed itself to the Improvement of the Town of Huddersfield by the Trustees has now been removed by the establishment of the Board of Improvement Commissioners': the HIC were empowered to lay out the capital and recover charges from holders of street frontage premises, including the estate and its tenants. ${ }^{64}$

The HIC's urban development role was strictly limited, however. It had no building control powers, leaving this to the estate, but did play a significant part in street works: by 1868 it would boast almost 10 miles of paved streets and eight and a half miles of main sewerage.${ }^{65}$ But the exercise of these powers brought recurrent tension between the HIC and the estate throughout the 1850s over their respective responsibilities for the fabric of new streets. ${ }^{66}$

The HIC was, in fact, a historic compromise between local democracy and the Ramsden interest. The democratic element was limited: of the 21 Commissioners, 18 were elected by ratepayers, but on a property-weighted franchise, while three were to be appointed by the lord of the manor.Although increasingly anachronistic, the CLWC's 1200-yard radius and confinement to the north bank of the river were retained, and while the Act allowed future extension, this was subject to the lord of the manor's agreement and was never pursued.

Unlike nominations to the CLWC, the estate took its three appointments seriously, at least in the earlier years. Over the body's 20-year term, 10 men served as Ramsden-appointed Commissioners. Loch took a seat himself for the first two years; of the remaining nine appointees, four were wool merchants, while only one (serving for two years) was a significant manufacturer. This indicates that the town's power brokers in this period were more often commercial than industrial. ${ }^{67}$ Notable among them were Joseph Brook (17871858), an architect of the 1848 Act who chaired the HIC from 1849-54, and his son-in-law Jeremiah Riley (1801-65). ${ }^{68}$ However, 1859/60 was the last year that three Ramsden appointees were in place, and for the HIC's last six years, 
1862-8, only the solicitor T. H. Battye, remained in post; his appointment in 1861 had followed considerable difficulty in finding anyone willing to serve. ${ }^{69}$

The Ramsden appointees were by no means mandated delegates. Riley, for example, reassured townsmen assembled at a New Year municipal dinner that:

On one or two occasions he had been told he had lost caste by resigning his position as a Town's Commissioner and accepting the nomination of the Ramsden Trustees. He wished to say that before he did this he wrote to know, if he accepted their nomination, whether they expected him to act with perfect impartiality and independence, and he had an immediate answer from $\mathrm{Mr}$ Loch stating that they would not offer it to any gentleman under any other condition than that he should be perfectly free. ${ }^{70}$

Conversely, Loch had declined to attend the same event in 1850 after receiving Hathorn's advice:

... as Sir John Ramsden's coming of age draws on quickly, I think it is desirable on many accounts to cultivate a friendly feeling with the people, but not in such manner as to compromise or affect in any way the perfect freedom and independence of the Trustees. ${ }^{71}$

The dinner itself, drawing together the various institutions, was first held in 1849. It signalled the emergence in 1848 of the kind of self-confident middle-class politics identified elsewhere in the 1820s and 1830s ${ }^{72}$ This had been slow to develop in Huddersfield, compared for example with Halifax, where the Piece Hall and Calder \& Hebble Navigation had been established collectively by the town's 'influential inhabitants' in the late $18^{\text {th }}$ century, not 'gifted' by the manor. ${ }^{73}$ But the railway campaign and creation of the HIC had now brought a stronger bourgeois civic politics to Huddersfield, albeit in a form which still bore the Ramsden stamp.

\section{NEW CIVIC FACILITIES}

Two substantial public realm initiatives flowed from the new nexus of an engaged estate and elective middle-class politics - one abortive, one successful.

The failed initiative at this stage was the construction of a town hall. A ratepayers' meeting back in 1843 had called for suitable rooms to be provided to accommodate meetings 'for every department of the Town's business' and to house all its civic documents. ${ }^{74}$ This was revived by the HIC, whose proposals for St George's Square in 1850 included a town hall site east of John William St.This was supported by the Huddersfield Chronicle, which continued to press for its inclusion in the improved Ramsden plans. ${ }^{75}$ Accommodation 
was proposed for the courts, HIC, HWC, Board of Guardians and overseers of the poor, all scattered around the town in varied premises, almost none of them purpose-built. ${ }^{76}$

At this point Hathorn and Loch became interested, recognising that it would be in the estate's interest to have a prestigious building with reliable tenants on a vacant site opposite their new George Hotel. ${ }^{77}$ The fifth baronet was nearing the age of majority and the trustees and agents were increasingly seeking his views. On this issue as on many others throughout his 60-year 'reign' as lord of the manor, he expressed an ambivalence - or attempt to have things both ways. As reported by Loch, Ramsden 'expressed a perfect willingness to go into it' and indeed wished 'quietly and as a matter of course to take the entire lead, so far as the design and arrangements of the building are concerned'; Hathorn was to inquire what was needed, but be 'very careful not to say anything that will commit Sir John to any pecuniary contribution'. ${ }^{78}$ Working with Hobson - with whom he had a fractious but pragmatic working relationship, mirroring that of the estate and $\mathrm{HIC}$ - Hathorn moved quickly to collate the various bodies' requirements, now including the Post Office, and his own suggestion for public halls and a dining room with a tunnel to the George! The consultation was complete, and the results with Loch, by early December. ${ }^{79}$

At which point the project stalled: all went quiet until August 1853 when the idea was revived by the newly-established Chamber of Commerce and a joint Chamber/HIC committee was set up. They re-engaged with Hathorn; he approached Thomas Nelson, the London solicitor who had just replaced Loch as chief agent, and a very cool response was received. ${ }^{80}$ Faced with seeming lack of interest from the estate, the joint committee nonetheless commissioned a 'suggestive design' from Charles Pritchett, son of the architect of the station. This can hardly have improved relations, as the Ramsden family had fallen out with Pritchett senior. ${ }^{81}$ The proposal became embroiled in local discussion about whether the ' $£ 20,000$ improvement fund' could be deployed in its support, and faded away. ${ }^{82}$ Sir William Tite produced a further proposal in 1856, presumably commissioned by the estate, for the Northumberland St site eventually occupied in 1914 by the Post Office, but that too went nowhere ${ }^{83}$ - though it was still in play 20 years later when the Town Hall debate resumed [see pp. 74-6].

The second public issue of this period, in contrast, was brought to a successful conclusion by 1855 . This was the town's burial crisis. By the early 1840s the parish church graveyard was shockingly full, with the sexton warning that he faced 'the utmost difficulty' in digging new graves without mutilating the bodies already there (said to be up to 19 deep). The vicar, the Revd Josiah Bateman, approached the estate, which owned the ground and 
appointed the vicars, for assistance - but apparently received no response from Bower. ${ }^{84}$ Five years went by, with conditions deteriorating, while efforts to find a solution without Ramsden support made no progress, largely because of tensions between Anglicans and Nonconformists. In January 1847 Bateman tried again and Loch responded immediately. Although he found it 'a matter of wonder and regret that sectarian jealousies and differences should have so long thrown impediments in the way of remedies that have been proposed ... $[\mathrm{T}]$ he horrors of the Church Yard however are so dreadful that I do think the Trustees would do well to entertain the request now made of them'. ${ }^{85}$

Initially a site at Hillhouse was proposed, linked to the trustees' endowment of St John's Church on the newly acquired Bay Hall estate. ${ }^{86}$ This fell through for several reasons, but the vicar took the initiative again in 1849, by which time the HIC was in business. Under Joseph Brook's leadership they vigorously took up the cause of a public burial ground, managed by the HIC and providing for all denominations. Brook and Loch had cordial working relations - they had been allied in achieving the 1848 Act and the railway settlement - and the eventual site at Edgerton was soon identified. But negotiations did not run smoothly, and it was not until 15 September 1852 that Loch handed over the site to Brook; the party then repaired to the George to celebrate Sir John William Ramsden's coming of age. It would be another three years before the cemetery opened on 8 October 1855.

The protracted negotiations of 1849-52 revolved around two issues which went to the heart of the relationship between estate and town in the middle decades of the 19th century, setting a pattern which recurs on other occasions. Whenever the town authorities wished to develop a public facility on Ramsden land, the price of the land and the credit for the initiative came into focus.

Regarding price, the estate usually argued that, as its lands were held in trust for future generations, it was obliged to seek market value for any disposals. This constrained it to operate as a profit-maximising economic agent within the land market. This was often in tension, however, with the sense of 'noblesse oblige' which went with being lord of the manor, and the desire for goodwill from the town. The fourth baronet and John Bower had neglected both aspects, and Loch's approach was strongly commercial: his 'primary concern was always with the improvement of the estate rather than the welfare of the people of the estate ... he had no sympathy with the traditional image of the landowner who accepted responsibility for the wellbeing of his people' ${ }^{87}$ But this was balanced by Earl Fitzwilliam and Isabella Ramsden, who were very conscious of the traditional responsibilities of the landed aristocracy and gentry towards what J.W. Ramsden would often refer to as 'my tenantry'. Once he was in sole charge, this underlying tension ran 
through Ramsden's own motivation and found expression in his characteristic ambivalence. ${ }^{88}$

In the case of the cemetery, Brook believed he had been offered the land at a nominal price, which Loch denied. When the latter appeared to reconsider the offer of the Edgerton site, Brook suspected this was because the estate had received a higher valuation for residential use - it would certainly have been a good site for villas, for which there was rapidly growing demand. ${ }^{89} \mathrm{He}$ also played on the estate's divided motives, writing to Loch that 'in the most respectful manner to you and the Trustees [whose nominee he was, of course] I cannot refrain from saying, that considering the immense stake the Trustees have in the town, it is incumbent upon them not to be only passive consenters, but to take an active and leading position' ${ }^{90}$ After considering several 'less eligible' sites, the estate eventually acquiesced in the HIC's strong preference for Edgerton. The land was initially valued at $£ 6,000$, but after HIC resistance fresh valuations were undertaken; a figure of $\mathcal{\mathcal { L }} 3,554$ was agreed; and half of this was then returned as a donation, a model to be followed again in later years. ${ }^{91}$ Along the way, estate steward J. C. Fenton, in a different tone from Loch, had given the young Sir John William Ramsden some sound advice on how to handle the town: he should support the proposal 'simply because the Huddersfield people wish for it, for in these cases it is always desirable to gratify them, unless there is (which there is not in this case) some very strong reason against complying with their wishes. ${ }^{92}$

The decade from 1844 had been very different from the previous 30 years. Land ownership had substantially increased.The estate had contributed, through speculative building and the release of its land, to major developments in public infrastructure, notably the railway, the new town and the cemetery - though much was still lacking. A historic compromise with other forces in the town had resulted in a more effective agency of local government, able to take forward the paving and draining of streets with new vigour, though there was tension as well as co-operation between the estate and the HIC, on which the town hall project foundered.

\section{Seeking a new balance, 1852-67}

Sir John William Ramsden's majority in 1852, and Loch's departure in 1853, marked a new turning point. Ramsden was now in charge, but of course utterly inexperienced compared with the retiring trustees, while Thomas Nelson, a lawyer through and through, was no George Loch. The next 15 years are harder to characterise than the previous 10.

Looking first at land ownership, if anything the pace of expansion slackened compared with the previous period, although there were significant 
acquisitions of the Clough House estate in 1858, Springwood in 1861 [see p. 66] and parts of the Firth estate in 1864 - though still not that 'one house' in the Beast Market. Instead, more attention was devoted to attempts to reform the estate's antiquated tenure arrangements. Even after the Ramsden Estate Acts of 1844 and 1848, it could only grant 60-year leases or tenancies at will, while neighbouring landlords such as the Lockwood proprietors and Thornhills were offering 999-year leases for both residential and commercial development. A further Act in 1859 allowed 99-year leases and also converted tenancies at will to these - a proposal at the heart of the 'tenant right' dispute. ${ }^{93}$ Finally the 1867 Ramsden Estate Act permitted 999-year leases, long after their use had become widespread on other urban estates.

These issues of estate management seem to have engaged far more of Ramsden's attention than the development of the town's public facilities. Nor, after the departure in 1854 of Brook from the chair and Hobson from the clerkship of the HIC, was there as much drive for development from that quarter, with the HIC focussing on its day-to-day sanitary and policing responsibilities. But two public realm issues during these years deserve attention - markets and public parks.

The upheavals of the 1840s had left untouched the estate's monopoly of the town's market rights, which embraced the Cloth Hall, the Beast Market and the general retail market in and around the Market Place. Some thought had been given to the creation of a new open market at Fleece Croft, below the parish church; Mrs Ramsden had proposed a covered market for women's domestic produce; and the George Hotel architect, William Wallen, had developed new plans for the Market Place itself; but none of these had come to fruition. ${ }^{94}$ Conflict arose in 1852 between the HIC and the estate over whether the latter had the right to collect tolls from stalls placed in public (HIC-maintained) streets. The problem was aggravated by the 'variable and increasing demands for tolls' from the estate's current toll-farmer, James Whitley; by confusion about the rights of the various parties; and by threats of litigation from both sides. ${ }^{95}$ As Edward Law explained:

Whilst the dispute arose from the annual May fair, popular feeling imposed the same objections to the actual Market Place, and whilst the Ramsdens had undoubted rights to market tolls, there were various matters which clouded the issue... The Ramsden estate managers appear to have taken an early decision to extricate themselves from the whole matter as diplomatically as possible. ${ }^{96}$

Their suggested solution, to lease the market rights to the HIC, was eventually achieved in 1864. There was, meanwhile, no further development of the town's market facilities by either party. 
The growing town also lacked a public park. Instead Edgerton Cemetery became a place of recreation: the large numbers walking its carefully laid out paths on Sundays in particular necessitated the appointment of keepers to ensure that order and decorum were maintained. ${ }^{97}$ However, it emerged in August 1858 that the 32-acre Springwood estate was about to come to market. ${ }^{98}$ Adjoining Greenhead, this was a surviving independent freehold close to the town centre, and its potential for residential development was immediately appreciated by Hathorn. But the Chronicle, now under Hobson's editorship, was quick to argue that:

A most favourable opportunity is now presented to secure for the use of the inhabitants of this district a place of public recreation immediately contiguous to the town, in a most delightful situation, and of easy access from every part ... an estate about 30 acres in extent, well fringed with wood, commanding a most extensive and magnificent hill-and-dale prospect, in itself most admirably adapted for the formation of walks abounding with the picturesque, and having on it a good mansion well adapted for a museum, for a public library, and for the accommodation of indoor parties. ${ }^{99}$

The suggestion was immediately taken up by the HIC and also by Nelson, who counselled Ramsden that:

the opening of such a place for the recreation of the Public would be considered an important acquisition for the Inhabitants and I think that your shewing that you took an Interest in it and were prepared to promote it by a liberal contribution would have a beneficial effect upon the minds of many. ${ }^{100}$

Ramsden took the point and made an offer which drew on the cemetery model. The HIC would buy the whole estate at the offer price of $\mathcal{K}^{22,435}$; he would contribute $\mathcal{E}, 000$ and solicit a further $\mathcal{f}^{2}, 000$ from the vendor, Sir Edmund Lechmere; the remainder would be raised by public subscription, not through the rates (which of course fell largely on the Ramsdens and their tenants). These terms were rejected by the HIC on 5 January 1859 when Ramsden's approach was contrasted unfavourably with that of Halifax industrialist Sir Francis Crossley, who had given the land for the People's Park to the town in $1857 .{ }^{101}$ The committee which considered the proposal had concluded that a public subscription appeal would fail "especially under the unsatisfactory relations between Sir John William Ramsden and his tenants in the Huddersfield estate', no doubt a reference to the tenant right dispute, which was then at its height. ${ }^{102}$ 


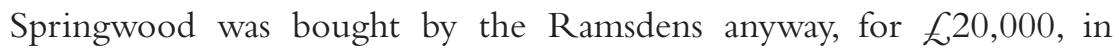
November 1861. This meant that they now controlled a complete arc of largely undeveloped land from the railway at Springwood through Greenhead and New North Rd to their St John's Church at Bay Hall, Birkby, offering ample opportunity for residential development on the favoured northwestern slopes of the town. In 1862-3 Ramsden and his agents sought to develop a master plan for the area, taking advice from London architect, William Habershon, and from the London builder (and Lord Mayor), William Cubitt. ${ }^{103}$ Had these plans gone ahead they would have been a town planning achievement to rank alongside the Georgian grid and Victorian new town, albeit in a suburban mode. But they did not: still limited to 99-year leases, the estate could not compete with the development of nearby Edgerton as the premier suburb, using 999-year leases from other landlords, especially the Thornhill estate.

A final light is shed on this period by the extraordinary six-page letter from Ramsden to Nelson late in 1859 , quoted in chapter $1 .{ }^{104}$ The immediate cause was the decision that Ramsden himself, rather than Nelson, should preside at the forthcoming annual rent dinner for his tenants; but a much wider point was made which confirms the view of Ramsden's biographer that

Jack was not an easy man to work with. Even with members of his team in whom he retained total confidence, he could rarely resist excessive micro-management, seeking to know, record and be involved in every detail of every decision taken. ${ }^{105}$

Reading between the lines, however, it seems unlikely that Nelson had his 'total confidence'; and the vastly experienced Hathorn was to leave in 1862.

In summary, this period was characterised by a slowed pace of land acquisition; limited contributions to the public realm; and a diminished interest in the HIC and town governance. Instead the lord of the manor and his agents turned their attention to the 'micro-management' of residential development, but only at the end of the period cleared away the last of the legal obstacles that stood in their way. The departure of experienced trustees and agents, and Ramsden's own personality and inexperience, played their part in shaping this less 'heroic' period.

\section{7-70: The world turned upside down?}

So far we have examined three major developmental episodes - the $1760 \mathrm{~s} / 1770 \mathrm{~s}$, the turn of the $18^{\text {th }}$ century, and the 1840s. The first two were entirely Ramsden-led, while the third resulted from a coalition of forces in which they were a leading player. The late 1860s saw a further shift in the 
balance, with the estate forced to respond to a major upheaval in governance initiated from the 'town'.

\section{THE COMING OF THE CORPORATION}

By 1867 there was a gathering consensus that the 1848 settlement was no longer fit for purpose. The town had spread far beyond the 1200-yard radius, but the 1848 Act's power of extension had never been pursued. Instead no fewer than eight local boards had been established in the surrounding hamlets and townships under the 1858 Public Health Act, while Fartown soldiered on with only vestry highway surveyors. The HIC launched a new drive for incorporation of the borough in May 1867 on a wider boundary than the township - and a Charter of Incorporation was gained in July $1868 .^{106}$

The estate's position on incorporation was deeply ambivalent. When he saw the draft Charter in July 1867, Ramsden wrote that 'Now that so much progress has been made towards obtaining the Charter I will no longer delay the expression of my desire to associate myself with a movement affecting so materially the future of Huddersfield' (and indeed the motion for incorporation at the HIC AGM in May had been seconded by T. H. Battye, the remaining Ramsden Commissioner). By September, however, Sir John was seeking a clause in the Charter which would preserve all his manorial rights 'as if the Charter of Incorporation had never been granted'. ${ }^{107}$

As the negotiations continued, Ramsden consulted a range of local and national lawyers and property professionals to establish the full range of his manorial rights. These were conveniently summarised as follows:

- Market rights under the 1671 Charter.

- The appointment of the constable (by the court leet).

- The appointment of four Commissioners under the 1827 Waterworks Act, and an annual payment of $\mathcal{N} 100$ as compensation for the estate's previous rights of water supply.

- The appointment of three Improvement Commissioners under the 1848 Act.

- The proviso in that Act that any extension of its jurisdiction should be on the joint application of the HIC and lord of the manor.

- The lord's right to name streets on his land.

- General provisos in the 1845 Waterworks Act and 1848 Improvement Act that nothing therein shall 'prejudice, defeat, lessen or affect' the manorial rights. 
At one time or another Sir John sought reassurance of continuity on all these issues, though some proved trickier than others. Market rights were a major bone of contention for the next decade [see p. 72]. The court leet survived until 1896, though latterly with purely honorific functions graced by an annual dinner, and the appointment of a constable continued at least until 1893; a proposal for the Mayor to hold the post ex officio was declined by the first incumbent, C. H. Jones, and not revived. ${ }^{108}$ The takeover of the HWC by the new Corporation in 1869 was not resisted by the estate, but the nomination rights and general provisos became significant bones of contention.

Ramsden initially sought the right to nominate three councillors just as he could appoint three Commissioners. Asked by R. H. Graham, Hathorn's successor, whether this was really an issue, Sir John characteristically said Yes and No:

I attach very great importance to the right of appointing three Councillors, though I will not say I attach so much importance to it as to make me an opponent of the application for a Charter, provided the Inhabitants act handsomely by me and do all in their power to have a Similar Right secured to me in the new governing body.

The issue was raised with the Privy Council Office (PCO), which handled incorporations, and Sir John was quickly made aware that there were no precedents for such a 'very unusual' arrangement. The issue having been explored, dignity was satisfied - at least for now - and by 20 June Sir John had stepped back from pursuing it ${ }^{109}$ - although one of Sir John's advisers did later discuss with the PCO whether the ward boundaries might be drawn to create a 'Ramsden-owned' ward where Sir John could nominate an alderman!

More troublesome was the quest for a 'general saving clause'. In March 1868, after the PCO had signed off the draft Charter, the matter was still causing delay. Finally after two days of discussions in London on 3/4 April between a deputation from the Incorporation Committee, Sir John and his legal advisors, the clause was withdrawn - but only on condition that, incorporation once granted, the clause would be inserted instead into future Bills extending the powers of the new Corporation, which all knew to be necessary. ${ }^{110}$ Although destined to cause future trouble, this cleared the way for the Charter to be promulgated on 7 July 1868 and for the first Corporation to be elected on 4 September. The formal representation of the Ramsden estate in the town's effective governing bodies had come to an end. 
Alongside the incorporation negotiations of 1867-8, the estate completed the reform of its tenure arrangements through the 1867 Ramsden Estate Act which, by authorising 999-year leases, removed the last barrier to the estate acting as an 'economically rational' property developer. Its role as lord of the manor, by contrast, was becoming increasingly anachronistic. The last annual rent audit dinner for the estate's tenants, which Ramsden had been so keen to attend personally in 1859, took place in 1870. As Ramsden had recognised by then, the dinners

... are not suited to the present condition of the estate. In fact that both the Town and the estate have outgrown them. That the numbers of the tenants have become so great that their meeting and dining together has become impossible, and that consequently the original significance of the dinners, as friendly gatherings where the tenants were to meet as their Landlord's guests ... has quite passed away. ${ }^{111}$

The 1867 Act also provided for further improvements to the estate, and allowed borrowing up to $f 50,000$ to achieve these, in addition to the earlier funds. The 'improvements' included the rebuilding of the 300-year old Longley New Hall which had doubled as a residence and estate office, and the creation of the new Estate Buildings, just off St George's Square, as a replacement office. ${ }^{112}$ Again this represented a shift of ethos from the antique domestic atmosphere of Longley, secluded from the town, to a purely commercial building in the town centre. Although opened 'without ceremony' on 14 September 1870, ${ }^{113}$ the magnificent Gothic edifice of Estate Buildings, designed by the local architect William Henry Crossland, can be seen as a very visible riposte to incorporation: there was a new settlement, perhaps, but the Ramsden estate had not gone away.

\section{PUBLIC FACILITIES}

In the coming decades, however, it would be the Corporation rather than the estate that took the lead in the development of the town's public facilities. ${ }^{114}$ But there were two pieces of unfinished business where tensions would soon arise between the estate and the new Corporation.

The first concerned markets. In November 1866 the HIC had pressed Ramsden to provide a covered market hall, which he had apparently taken

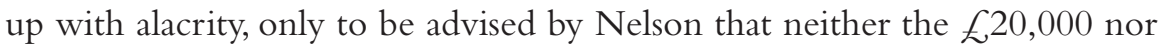
the $f^{25,000}$ improvement fund could be used for this purpose, for the usual complex legal reasons. ${ }^{115}$ He had evidently chafed at this advice and the 1867 Act included specific powers to erect new markets, authorising expenditure 


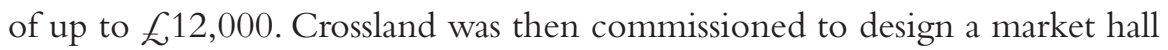
on a site bounded by King St, Cross Church St and Kirkgate (essentially where the Kingsgate shopping centre is today). He produced a block plan and an itemised estimate of $\mathcal{f} 33,244$, though no detailed designs have come to light. ${ }^{116}$ Clearly the estimate was far more than the authorised funding and the proposal went no further.

The second outstanding issue concerned the town's premier public space, St George's Square. Like almost all the town centre, this was owned by the estate. It had not been adopted as a public street by the HIC. In the 1850s an 'ornamental centrepiece' had been planned, but no designs had been produced to Ramsden's satisfaction, and the space had been left for 'open air meetings at elections and other like purposes'. ${ }^{117}$ It was therefore open to the estate to enclose the space, and in 1866 designs to fence it in had been drawn up by Graham but not taken forward. With the advent of the Corporation, Ramsden saw an opportunity for a different solution to what had perhaps become an embarrassment. The state of the Square, Graham wrote at one point, was 'a disgrace to the town', and in April 1870 the land was offered to the Corporation provided that they paved it and on condition that the estate's permission would still be required to erect anything there. The issue remained unresolved in 1872, when it became embroiled in controversy about a proposed statue of Sir Robert Peel [see pp. 73-4].

\section{0-1910: a long withdrawing roar?}

In his comparative analysis of 'lords and landlords', David Cannadine suggests that the last two (of six) phases of the relationship between landed proprietors and 'their' towns in the late-19th and early-20th centuries were 'ornamental impotence' followed by 'territorial abdication'. ${ }^{118}$ In the Ramsden case, this latter was reached in $1920 .{ }^{119}$ For the post-incorporation period, however, 'ornamental impotence' is too simple a description of the tense relationship between the lord of the manor and the municipal authority.

There were certainly ornamental elements. In his July 1867 welcome to the draft Charter, Ramsden had expressed a wish to present the Mayoral gold chain and badge of office and, after the intervening fraught negotiations, he was as good as his word, presenting them in person to C. H. Jones at a public dinner on 5 February 1869 at the George. ${ }^{120}$ Moreover the new Borough's arms, with their rams' heads and castellated 'dens', were closely based on those of the Ramsdens [see back cover]. Over the coming decades, as Brendan Evans has put it:

There were many examples of deference and respect from the Council to the influential local landowner: for example, when HBC wished to 
open a footpath through his land they very respectfully asked Sir John, through his agent, for his permission. Members of the Ramsden family were frequently invited to open a new building or bridge, which would often take a family name, and were always asked in the politest and formal terms, with great gratitude expressed when the family agreed. ${ }^{121}$

But cordiality was accompanied by a hard-headed defence of estate interests and equally by a zealous assertion of the Corporation's independence.

PUBLIC REALM CONTROVERSIES OF THE I87OS

The April 1868 agreement to incorporate a 'saving clause' in future local Acts was activated in 1871 when the Corporation put forward a 463-clause Bill establishing new powers, going far beyond those inherited from the HIC and the local Boards to cover street works, sewers and lighting; building regulations and licensing; smoke control and a fire brigade (established in 1872); parks, baths and libraries; and the erection of a town hall.

The estate's greatest immediate concern was with its market rights. Its motives seem (as so often) to have been mixed. As Graham later recalled to town clerk Joseph Batley, 'Sir John Ramsden himself was averse to alienating the Fairs and Markets, and only consented to do so in order to meet the wishes of the Corporation'. In 1871, therefore, he had renewed his proposal to build a covered market and offered to lease it, with the rights, for 21 years and then to sell the freehold. A corporation deputation to Byram on 7 February failed to resolve the issue, and the Corporation then sought to include compulsory purchase in the Bill before Parliament, which the estate believed violated the saving clause. They prevailed in the Lords and 'even more emphatically' in the Commons, and at the end of June Graham could telegraph Ramsden to report that 'the whole of the Markets Clauses ... thrown out'. ${ }^{122}$ Mayor Jones reported back furiously to Council on 19 July without donning the Mayoral chain, vowing that henceforth 'I will not have those bobbing rams' heads stuck around me'. ${ }^{23}$

After this stand-off, however, and with the combative Jones replaced as Mayor by Wright Mellor, ${ }^{124}$ negotiations for the sale of the rights were reopened in 1872 and concluded in 1874. It remained to haggle over the price - resolved in 1876 with the Corporation agreeing to pay $\mathcal{E}^{3} 39,802$, plus interest to reflect the delay since exchange of contracts. Only in 1879, however, was the conveyance finalised, after difficulties over butchers' leases. ${ }^{125}$ The new municipal Market Hall, designed by another distinguished local architect, Edward Hughes, opened in 1880 in King St, and a new cattle market and slaughterhouse in Great Northern St in 1881. 
The negotiations over market rights were paralleled over the same years by the Corporation's attempts to buy around half of the Greenhead estate in order to create Greenhead Park. Unlike the markets, and despite their opportunistic Springwood initiative, the Ramsdens had no inherent interest in that quintessential piece ofVictorian public realm, the public park. The land they held at Greenhead was a prime residential site, which they had owned since 1848 and were now well-placed to develop. Plans to do so were noticed at the estate office by Alderman Thomas Denham in 1869; he resolved that the land should instead be 'secured for the town' and soon persuaded the Corporation to adopt the proposal. From that point it took 12 years of onoff negotiations before the town finally acquired a park of 30 acres, half the size envisaged by Denham, in 1881. Once again, Ramsden was torn between the prospect of more lucrative development and the reputational benefit of a generous gesture towards the town. Eventually, in a reprise of the 'cashback' arrangement adopted at the cemetery and proposed for Springwood, the

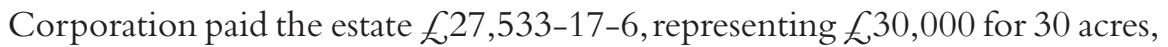
plus interest at $5 \%$ since 1878 , when terms had been agreed, less a donation from Sir John of $£, 5,000 .{ }^{126}$ The estate then lost no time in capitalising on the splendid residential sites overlooking the new Park. As a report of the opening noted: 'All round the park Sir John owns the frontage, and must gain an immense advantage from a monetary point of view, as the value of the land will be trebled for building purposes.' ${ }^{127}$

Another cantankerous dispute of the 1870s concerned the statue of Sir Robert Peel in St George's Square. Throughout the country Peel was regarded as a hero for the repeal of the Corn Laws and consequent reduction in food prices. On his death in 1850, in Huddersfield as in many other places, gentlemen's and working men's committees had been established to raise funds for a monument, and within a year many subscriptions had been raised. When the time came to choose a sculptor, however, dissension led to years of infighting and committee arrangements became confused. By 1868 there were only 10 surviving committee members, five of whom had left the town. A new committee was formed and a successful new fund-raising drive launched. On 21 October 1869 the committee announced that they had accepted the model of William Theed the younger for a statue which was to be in Sicilian marble. ${ }^{128}$ Committee member G. D. Tomlinson, a local artist, invited Ramsden to view the model, which he did, recording that he was 'very favourably impressed with the general effect'. ${ }^{129}$

Over the ensuing two years, as Theed worked on the statue, the Corporation and Ramsden remained at odds about future control of the Square (as noted above). In July 1872, however, Graham found from a newspaper report that the committee had been granted permission by the Corporation to place 
the statue in the Square. This was a serious faux pas. Receiving the news, Ramsden responded that 'I object very decidedly as you know to the use of the Square for such a purpose', that the usage of the Square remained in his gift, not the Corporation's, and that his London lawyer Wynne was to be consulted. ${ }^{130}$ The chastened committee now sought permission for an alternative site, perhaps in the Market Place. Initially acceptable to Ramsden provided it did not interfere with the market cross, ${ }^{131}$ this was later ruled out too. In the end the railway company allowed its erection on their own land in front of the station, where it was unveiled on 3 June 1873 [see Illustration 22, p. 59]. It stood there until 1949 when, because the stone was deteriorating, it was removed and lost; the empty plinth survives in Ravensknowle Park.

For the estate and Corporation, however, that was not the end of the matter. As its ambitions grew, the Corporation put forward a new Improvement Bill in 1876. This was less voluminous than its predecessor but its 141 clauses advanced many new powers and, as in 1871, attracted a wide range of objections from the estate. Once again matters were closely fought in Parliament, not least the innocuous-sounding Section 69, 'Drinking fountains, $\& c$ '. This empowered the Corporation to 'place and maintain in any street or court any monument or statue, ornamental drinking fountain, and troughs as they think fit'. In Graham's words, 'if this clause passes, Sir John ... will be driven in self defence to rail in any open space not actually required for street purposes'. ${ }^{132}$ The upshot was the addition of a second paragraph, providing

that no such monument or statue, drinking fountain or trough, shall, except with the consent of Sir John Ramsden, be placed on any part of the public square or open space called St George's Square or of the triangular piece of ground bounded by Spring Wood St, George St, and Upperhead Row ['Sparrow Park'], or of the triangular piece of ground bounded by Ramsden St, St Paul's St, and the public footway running along the north side of St Paul's Churchyard, or of any other ground or open space which Sir John Ramsden may hereafter appropriate or dedicate to public use and which the Corporation may on behalf of the public accept.

Sir John was here reasserting, in no uncertain terms, his intention to retain control of the symbolic features of key public spaces, even where he was willing to concede to the Corporation the right (and the cost) of maintaining them. ${ }^{133}$ Moreover, he obtained an extension of his street-naming powers from the old 1200-yard 'improvement district' to the Borough as a whole.

It was perhaps for similar reasons that he opposed the erection of the new Town Hall away from the 'new town'. Starting life in the Philosophical Hall, in 1875-8 the Corporation had built modest Municipal Offices in 


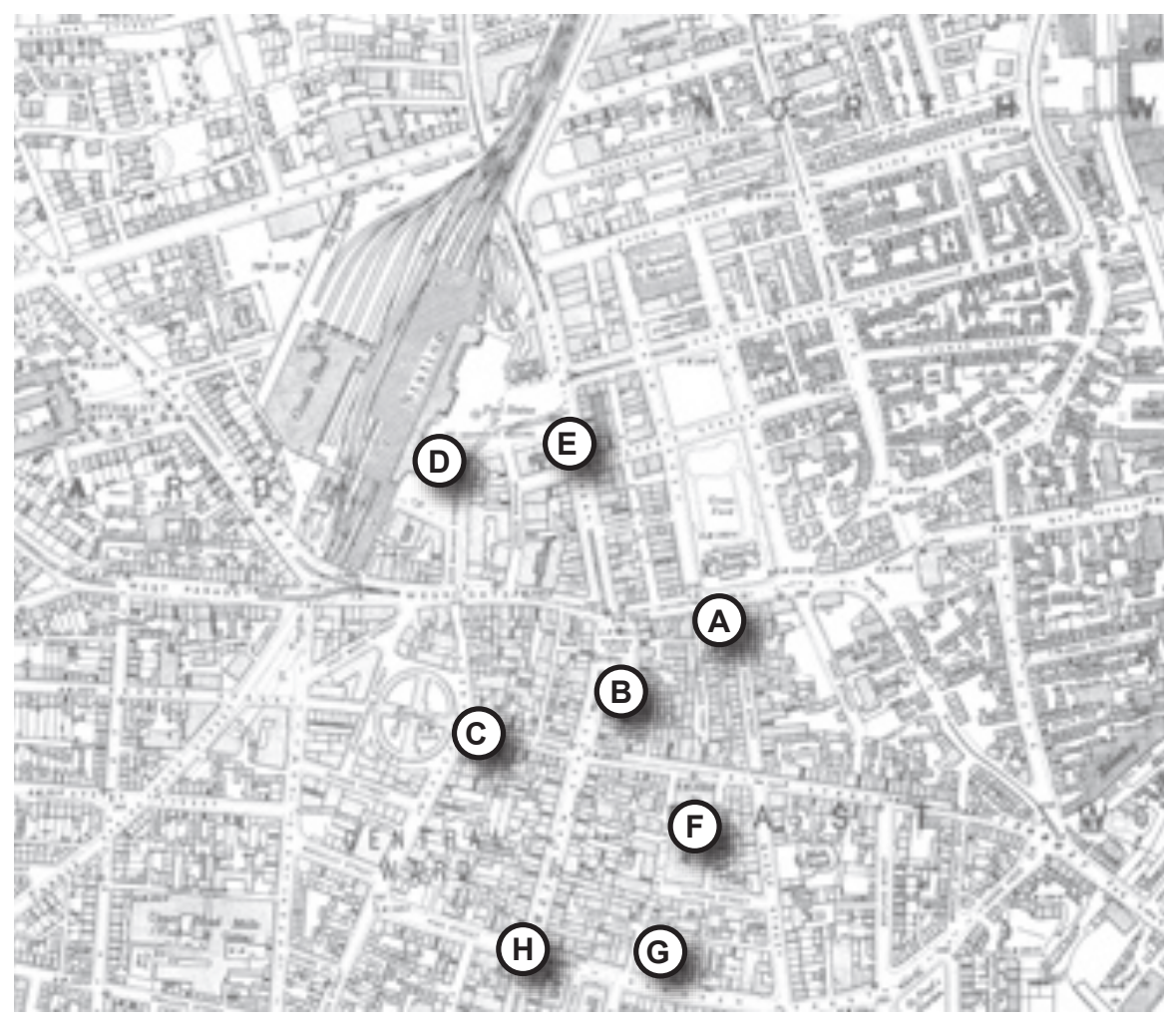

24. 1907 Ordnance Survey street map (1:25,000), showing Victorian development

The central area of the town is now fully developed, with building reaching well beyond Ramsden Street to the south. The Parish Church (A) is still located centrally and the Cloth Hall (C) remains prominent, but the largest feature is now the Railway Station (1846-50) (D). Better-class housing has appeared in West Parade, Trinity Street and New North Road to the north-west, and there is industrial development and lower-grade housing down towards the canal and river to the east. To the north a whole new town has appeared, approached along John William Street from the Market Place (B), past St George's Square and the George Hotel (1849-50) (E), and reaching well beyond Fitzwilliam Street at the top of the map. The Shambles has now been replaced by the Market Hall (1880) (F), and almost opposite the Ramsden Street chapel $(\mathrm{G})$ is the new Town Hall (1875-81) (H).

Huddersfield Local Studies Library

Ramsden St, within the existing 'civic quarter'. In 1877-8 they proposed to add the much larger Town Hall behind the Offices, with concert hall, court and further offices. ${ }^{134}$ As Pamela Cooksey writes, Joseph Woodhead, Mayor in $1877 / 8$ 
had the most acrimonious disagreement with Sir John Ramsden as he and the members of the Town Council sought to build a Town Hall in Princess Street - a site leased from the Ramsden estate. Sir John Ramsden supported by other leading influential local property owners was totally opposed to the proposals and refused to co-operate in any way with the Council.The dispute was so intense that Joseph declared to the Council, 'Gentlemen, this is now not merely a question of Town Hall or no Town Hall, but the independence of the Town Council. We are not representatives of the Ramsden estate but of the burgesses of Huddersfield. ${ }^{135}$

It is fair to add, however, the burgesses were divided, with a large body of wealthy ratepayers agreeing with Ramsden that the Northumberland St site he had reserved for a town hall since the 1850s would be the 'most eligible' site, in a central position near the station and post office and with room for later expansion of civic facilities. ${ }^{136}$ The arguments were practical but also symbolic: a site in the 'civic quarter' versus one half a mile away in the Ramsden-created commercial new town. For better or worse, the Corporation prevailed.

\section{QUIETER TIMES FROM I880}

The relationship between the estate and the Corporation weathered the storms of the 1870 s, and by about 1880 settled into a mutual accommodation lasting several decades. This period had several features:

- The estate continued to petition Parliament against aspects of successive local Acts brought forward by the Corporation, for example in 1880,1890,1897, 1900 and 1906. But the grounds of objection were increasingly narrow and more technical, usually concerning particular proposed acquisitions of property, for example for street improvements or tramways. The hard-fought saving clause made its last appearance in the Huddersfield Corporation Act 1897. ${ }^{137}$

- As the Corporation continued to extend its functions, however, the estate proved willing to sell land to enable this. In 1880 and again in 1890 land at Deighton and Dalton was sold for the sewage works; in 1887 for the open produce market in Brook St; and in 1892 for 'Fartown Recreation Ground', opened in 1893 as Norman Park. ${ }^{138}$

- The estate, or Ramsden personally, made occasional donations of public facilities apparently without any specific ulterior motivation. He had given $\mathcal{E} 1,200$ in 1872 to buy land for an extension to the Infirmary, 
and in 1887 had offered a floor of Somerset Buildings rent-free for a library and art gallery, though the Corporation - pioneering in many areas but laggardly on this front - had not taken it up. ${ }^{139}$

- From time to time they also brought forward larger schemes which combined commercial motivation with public benefit. Notably, 1876-86 saw the erection along Byram St of three handsome commercial buildings, Waverley Chambers, Bulstrode (now Kirkgate) Buildings and Somerset Buildings, all designed by W. H. Crossland. The estate's outlay of over $£ 120,000$ (including nearby Byram Arcade) was undoubtedly a commercial development but, facing the parish church and St Peter's Gardens, these buildings created the town's best public space after St George's Square. ${ }^{140}$

But the Ramsdens' legitimacy as anything more than commercial landlords was steadily diminishing: 'as the century wore on and more and more ... local functions transferred to the State, it became progressively more difficult to legitimize the traditional hierarchy in terms of those local functions. ${ }^{141}$

\section{LAND OWNERSHIP AND MANAGEMENT}

After 1868, while the estate faced the necessity of reaching a new accommodation with 'the town', it retained its powers of initiative as a landowner. Perhaps it was no coincidence, then, that the next decade and a half saw the most energetic expansion of the estate's holdings. The years 1868 to 1884 saw over 20 acquisitions. These included large estates in outer parts of the borough, such as the Woodhouse, Fell Greave, Woodside and Sheepridge estates to the north, and the Kaye estates at Moldgreen and Dalton. But there was also a steady stream of smaller purchases in or close to the town centre, in such locations as Newhouse (Highfields), Trinity St, Lord St (Firth's freehold at last!), Shorehead, Spring Grove and Gledholt. ${ }^{142}$ It was, in fact, only in this period, that the estate's town centre holdings approached the near-monopoly position often asserted or implied in earlier times. More widely, by 1884 the Ramsden estate held 51.5 percent of the township, and 41.4 percent of the 10,496 acres of the Municipal Borough - essentially the 4,300 acres that would be sold to the Corporation in $1920 .{ }^{143}$

In the absence of public town planning powers before 1909, this made the estate a surrogate planning authority. In 1886 the estate set out its town planning principles to the Parliamentary Select Committee on Town Holdings. In Huddersfield, they reported: 
certain districts are set aside for certain purposes. The centre of the Town is devoted to Shops and Warehouses, and the vacant land is reserved for future extensions of these. The lowlying land between the River and the Canal is allotted to mills and manufacturing premises, and their future extensions - other parts are residential and set apart for private houses of various sizes and values. ${ }^{144}$

There is nothing here to challenge David Cannadine's argument that 'for all [the Ramsdens'] tight legal control, the zoning pattern remained primarily influenced by topography'. ${ }^{145}$ The real purpose of the submission, however, was to resist proposals for the taxation of vacant land. Considerable land, it argued, had been bought, sewered and paved by the estate for which there was as yet no great demand; but when there was, values would rise and ratepayers would benefit, so there was no detriment from holding it vacant meanwhile.

But perhaps this long-term view had now gone far enough, for it was at about the same time that the estate's 40-year campaign of land purchase came to an end. And while Graham in 1880 had described Ramsden as 'a very reluctant seller of land in any circumstances', ${ }^{146}$ the estate was now willing to embark on a number of freehold sales. Once again, a change of personnel may have played a part: Graham died in 1885, to be replaced by Col. Beadon. The estate relaxed its remaining paternalist attitudes, abandoning its resistance to back-to-back housing in 1900 (though new back-to-backs would anyway be outlawed in 1909) and adopting rental policies which favoured a quick return over long-term estate development. ${ }^{147}$

To attempt a summary of this period, including the turning point of 1867-9, is more challenging than its predecessors; indeed there is a case for a division into two sub-periods. From 1867 to about 1880, the estate's relationship to the public realm revolved around the terms of the Borough's belated incorporation and the definition of its relationship to the new municipal authority, which had 'ornamental', pragmatic and conflictual elements. ${ }^{148}$ As a landowner, meanwhile - and perhaps in response - the pace of estate expansion was quickened and major developments in the 'new town' asserted that the estate was by no means a spent force. As for day-to-day estate management, the 1867 Estate Act had removed the last barriers to rational landlordism, though the estate continued to take a long-term view of its assets in the 'country estate' tradition. From the early 1880 s, however, the balance shifted again. Tension with the Corporation continued but over a narrowing range of issues, very much reflective of 'commercial landlord' rather than 'lord of the manor' concerns. There were occasional philanthropic gestures towards town facilities, albeit sometimes entwined with commercial proposals. Land acquisition was largely at an end by 1885, and by the turn of the century, 
though still owning half the town's land, the estate behaved increasingly as a rational but short-termist rentier, in a sense returning to its early 19thcentury outlook.

\section{0-20: the last goodbye}

On 31 March 1910 Ramsden made over the Huddersfield estate to his son John Frecheville Ramsden (1877-1958) - as he put it, he had 'abdicated in his favour'. ${ }^{149}$ It is tempting to see this as the beginning of the end, with John William Ramsden's death in 1914, World War I and the sale of the estate to the Corporation all to come within the next decade.

The son's initial reaction seems, however, to have been a renewed sense of ambition for the estate to take an active part in Huddersfield's development. A series of typed letters from Sir John Frecheville to the agent Beadon shows that several new improvement schemes were under discussion - although only one would come to fruition, and several only reprised earlier ideas. ${ }^{150}$

One was a new proposal to erect a public library and art gallery to the north of the parish church, either on part of the churchyard or on the stillempty 'town hall' site in Northumberland St. Like its predecessor this did not go forward, and the town would wait until 1940 for its purpose-built library in Ramsden St. Meanwhile the Northumberland St site was finally occupied by a new Post Office, which opened in 1914 to replace Crossland's building of 1877 on the opposite side of the street.

This discussion revealed problems with the state of the parish church itself. The Ramsden family had contributed to the rebuilding of 1834-6 but that job had been ill-done by the contractor and the stonework had caused problems ever since (and still does). ${ }^{151}$ Sir John Frecheville was now willing to support rebuilding on the same site, with a temporary church in Lord St while the work was undertaken. His letters show a close and intelligent interest in the details of both schemes, but neither went forward.

One project which did come to fruition - unlike the housing proposals of 1890 - was the building of Oldgate tenements. An earlier offer of land for working-class housing down Leeds $\mathrm{Rd}$ in 1890 had not been taken up. ${ }^{152} \mathrm{As}$ Cyril Pearce relates:

From 1882 to 1909 , successive administrations in Huddersfield town hall listened to the calls for more working class housing, whether from the Medical Officer of Health or, after the 1890s, from the local labour and socialist movement, but felt unable to respond. However, new powers made available to local authorities by the [1909] Town and 
Country Planning Act encouraged a change of heart. Ironically, at this point, after decades of declining influence, it appears that the Ramsden estate decided to take the initiative and goad the Corporation into action. A site on Oldgate was identified and plans drawn up by K. F. Campbell, the Borough Engineer, acting for the Ramsden estate, were approved by the Council on 15 February 1911. Less than a year later the Ramsden tenements, Huddersfield's first, were completed. ${ }^{153}$

As well as the town centre tenements, Sir John Frecheville was also 'interested to hear that a scheme for a Garden City has been brought forward' - in Dalton - and was 'anxious to do all in my power to help it on'. He was willing to sell land to the promoters at $£ 250$ /acre (a quarter of his father's price for Greenhead Park 30 years earlier), noting that out-of-town development was good for the estate. Hearing that Beadon was to visit a garden city development in Liverpool, he was keen to come too. ${ }^{154}$ Shortly afterwards a plan was drawn up for a new garden suburb on land adjoining Edgerton cemetery, between Highfields and St John's church, in a return to the unrealised residential master plans of the 1860s. ${ }^{155}$ Once again nothing came of this and indeed another century was to pass before any part of the site was taken for housing.

Whether Sir John and his agents could have brought more of these plans to fruition, had war not intervened, cannot be known. In the judgement of Meriel Buxton, it seems unlikely:

There can have been few less propitious moments in British history than 1914 for a business empire, which essentially was what the Ramsden estates had become, to pass from the control of a man who enjoys making money to one whose sole interest is in spending it. ${ }^{156}$

It is, in any event, a matter of fact that, once the war was over, the Ramsdens were ready to sell, and the Corporation was ready to buy. Henceforth the responsibility for the public realm would, for some time, be theirs alone.

\section{Conclusion}

The Ramsden family and their agents had an immense influence on Huddersfield's public realm over 250 years, and their impact remains highly visible a century after they sold out. Nonetheless it is an over-simplification to see Huddersfield uncritically as having been a 'Ramsden town'. This chapter has attempted to establish a more nuanced picture, differentiating between periods, geographies and dimensions of influence. Several trends and patterns have been identified:

First, the estate's land holdings in Huddersfield grew substantially from relatively small beginnings to the 4,300 acres sold in 1920. Far from 'owning 
the town' throughout the period, however, the most vigorous growth was from the 1840 s to the 1880 s, and especially after 1868 .

Second, there is a cyclical pattern to the estate's development of the town's facilities. The market rights were acquired in 1671; the Cloth Hall and Canal established in the 1760s and 1770s, followed by the Georgian town centre; the railway-based new town developed from the late 1840s. Between and beyond these developmental episodes were long periods of retreat from active engagement in town affairs.

Third, there is a long-term shift from a paternalistic to a more commercial relationship to the town, but this was not a simple transition: the elements were intertwined over a long period.

Fourth, these trends interacted to produce a succession of different institutional settlements for the governance of the town. The Ramsdens were always a player in these, and particularly in the case of the 1848 Improvement Commissioners. Paradoxically, however, the HIC's establishment also evidenced the emergence of an independent middle-class civic politics which had been somewhat retarded by the strength of the Ramsden interest, but which now came to challenge it. From 1868 the estate's rise as a landowner was accompanied by its ejection from formal governance, leaving a complex relationship with the new municipal authority.

Fifth, the estate's political grip on the town has been exaggerated. There was always room for independent radical politics, the estate's policies were often strongly contested, and Huddersfield was never a 'pocket borough'. The estate often worked through alliances with other forces, notably the town's leading merchants. These were often Tories: the Ramsdens, Whigs and Liberals themselves (at least until the 1880s), were always pragmatic about their local allies.

Finally, although long-term historical trends were at work, the impact of personalities is striking. The third and fifth baronets had more in common with each other than with the fourth, during whose later years the town languished. Agents were equally diverse in their approaches; and two periods of trusteeship, led by strong family figures, were important in initiating the key developmental episodes. As always, the interplay of personality and circumstance turns out to be the stuff of history.

\section{Acknowledgements}

For comments on an earlier draft, I am grateful to Brian Haigh, John Halstead, Cyril Pearce and the editor. Dennis Whomsley's work, much of it unpublished, has been indispensable. Any remaining errors or misjudgements are of course solely my own. 


\section{Endnotes}

1 Journal of the House of Commons, xxxiii, 414.

2 KC311/18/13, Township Papers, Huddersfield: Report on the Borough of Huddersfield; with a Description of the Proposed Boundary.

3 Cannadine (1980), p.42. Huddersfield was not one of his detailed case studies, but his later point, that 'we still await a study which deliberately and self-consciously investigates the position of the Ramsdens in the public life of the town' (Cannadine (1982), p.12), is one inspiration for this chapter.

$4 \quad$ Gash (1953), p.xi.

5 Springett (1982), p.131. She cites other official sources of the 'opinions', e.g. Reports of the Select Committee on Towns, 1887/88/89.

6 Hemingway (1992), pp. 497-8. Hemingway considered the period 1832-53, but Dennis Whomsley records Sir John William informing local agent Thomas Brook in 1859 that 'I have always given strict injunctions to my agents not to interfere in elections' - see Whomsley, 'Sir John William Ramsden and the West Riding, 18591867', unpublished typescript, KX486/2.

7 This section relies heavily on the work of earlier scholars, especially Dennis Whomsley. His unpublished work, now deposited at KX486/2, as well as his published papers, are gratefully acknowledged.

$8 \quad$ Law (1992), p.66.

9 Whomsley (1984), p.37.

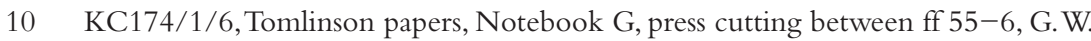
T[omlinson], 'The Firths of Shepley and Huddersfield', The Watchword, pp. 77-8. Thomas Firth (1789-1869) was a wealthy Quaker drysalter (f.71). The transaction did not proceed.

11 Dawson (1973), p.181.

12 Phillips (1848), p.1.

13 DD/RE/447 (copy of 1893).

14 WYASK, Ramsden estate plan 1780; WYAS, Wakefield, John Goodchild collection, Hirst \& Kennet estate map, c.1780 (copy at WYASK); WYAS, Wakefield, QE13/2/9 \& 15, Land Tax returns, 1780-1832.

$15 \mathrm{DD} / \mathrm{RA} / \mathrm{C} / 27 / 6,1873$.

16 Ahier (1949), p.81.

17 Woodhead (1939), pp.22-8.

18 Crump \& Ghorbal (1935), p.106.

19 Whomsley (1984), p.30.

20 Whomsley, 'The Ramsden family, 1670-1776', unpublished typescript, KX486/2.

21 Whomsley (1984), p.33, citing J. Aikin (1795), p.128 and J. Hewitt (1862-4), p.290. The Ramsden Canal was later complemented by the Huddersfield Narrow Canal, linking to the west. This was not a Ramsden initiative, but Sir John was nominally a director in the company's first year and his steward, John Crowder, represented his interests as an active board member during construction. (T. Ellis, 'Huddersfield Canal Company Committee', unpublished, n.d.).

22 Whomsley, 'The Ramsden family, 1769-1839', unpublished typescript, KX486/2.

23 Whomsley (1984), p. 35.

24 Law (2001a) reports that Cloth Hall St, though misleadingly added to the 1778 town map, 'was not promoted until the 1790s'; George Redmonds notes New St rentals from 1798; the first plot in King St was let in 1802 (DD/R/dd/7/55) and seven properties there appear in the $1807 / 8$ Ramsden rentals (DD/RE/r). 
25 Girouard (1990), p.180.

26 Whomsley, '1769-1839', p.15 and (1984), p.35.

27 Whomsley (1984), p.31; indeed Thomas had appointed him, in 1769.

28 In 1818 Bower was involved in 'several overlapping enclosures ... which may well have slowed up the process' of the Shipley enclosure, where he was commissioner: Coomber (2017), pp. 357-8. In 1835 he was forced to resign a post with the Duchy of Lancaster because of 'inattention to duties': Hilton (1989), p.26.

29 Springett (1982), p.132.

30 See chapter 3.

31 DD/RA/C/4/1, 'Why should not Huddersfield become one of the best regulated towns in the Kingdom?'. The quotation appears in Friedrich Engels' 1845 Condition of the Working Class in England (Engels, 1886), although not verbatim as it has been re-translated into English. The consequences of the tenancy-at-will system have been closely examined by Jane Springett (1979), and the 'tenant right' dispute which brought the system to an end is the subject of chapter 3 below.

32 The governance of this period is fully analysed in Griffiths (2008).

33 The minutes are at KMT98, Huddersfield County Borough records.

34 The court records are at DD/R/M.

35 For details see, for example, Hargreaves (1992).

36 See Hemingway (1992).

37 Whomsley, '1769-1839' pp.19, 26.

38 Navickas (2016), p.175. The judgement is echoed by Roberts (2018), p.53.

39 For details, see Griffiths (2008).

40 Springett (1979), p.16.

41 Moore (1976), p.344.

42 Whomsley (1984), p.48.

43 Springett (1979) gives the fullest account of the legal issues surrounding the Ramsden estate.

44 Engels (1845 [1987]), p.82.

45 Griffiths (2012).

46 Woodhead (1939), p.48.

47 HC, 24 April and 1 May 1858.

48 See Whomsley (1974) for a thorough analysis of the Ramdens and the railway question.

49 R. Oastler, 'A letter to the editor of the Argus and Demagogue, on the validity of Sir John Ramsden's title to the sums of money he claims for canal dues, and on other subjects', published as a booklet by Joshua Hobson, 1834. I am grateful to Brian Haigh for this reference.

50 Whomsley (1974), p. 191, quoting Fenton to Fitzwilliam, 1 March 1844.

51 See chapter 1.

52 Spring (1963), p.89. His significant part in the Highland Clearances, on behalf of the Duke of Sutherland, should not go unmentioned.

$53 \mathrm{DD} / \mathrm{RA} / \mathrm{C} / 24$.

$54 \mathrm{DD} / \mathrm{RA} / 4(1)$.

55 The 'stately home' description was by architectural journalist Ian Nairn ('Football Towns', The Listener, 1975) and not, as is sometimes suggested, by Sir John Betjeman.

$56 \mathrm{DD} / \mathrm{RA} / \mathrm{C} / 36$, Hathorn to Loch.

57 Clarkson (1989), pp.7-12.

58 The Bay Hall purchase preceded the canal sale, but Isabella Ramsden advanced the funds until the Trustees could reimburse her. 
59 Ramsden Estate Act, 7 \& 8 Vic, cap.21.

60 DD/RE/419, Isaac Hordern's Notebook, 1846, pp. 5-6.

$61 \mathrm{DD} / \mathrm{RA} / 4$, Loch to I. Ramsden, 30 December 1849.

62 Springett (1986), p.45.

63 Griffiths (2009).

64 DD/RA/4, Loch to Mrs Ramsden, 30 December 1849.

65 Joseph Batley's evidence in Municipal Incorporation of Huddersfield: Report of the Proceedings of the Public Inquiry, 18/19 December 1867 (HC, 1868).

66 There are numerous examples in the HIC minutes, KMT18/2/2/1.

67 Thus continuing into the third quarter of the 19th century a pattern identified for earlier decades in Griffiths (2015).

68 The first chairman, John Sutcliffe (1776-1858), was another wool merchant, who corresponded extensively and confidentially with Isabella Ramsden on town affairs (DD/RA/C/4/1-4).

69 As many as nine possible candidates are discussed in Ramsden correspondence, none of them manufacturers: DD/RA/C/38/1, 10 July to 26 September, 1860; DD/

$\mathrm{RA} / \mathrm{C} / 40 / 5,6$ September to 16 November 1861. Other membership information has been drawn from correspondence scattered through the DD/RA and DD/RE/C series.

70 HC, 25 January 1851.

71 DD/RE/C/78, Hathorn to Loch, 11 November 1850.

72 Chase (2013), p.276; Saville (1988), pp.37-9; Morris (1990); Griffiths (2015).

73 Smail (1994), pp.122-46.

74 KC790/2, Huddersfield Township records, Ratepayers' meeting, 6 April 1843.

75 HC, 13 April 1850. Hathorn attributed the editorial to Hobson, who was widely seen to be 'moonlighting' for the Chronicle alongside his HIC duties; after dismissal from the HIC, over matters including his attendance at work, he became the editor in June 1855.

76 These are detailed in Griffiths (2012), pp.14-20.

77 DD/RE/C/79, Hathorn to Loch, 12 December 1850.

$78 \mathrm{DD} / \mathrm{RE} / \mathrm{C} / 88$, Loch to Hathorn, 28 September 1851.

79 DD/RE/C/88-91.

80 KMT18/2/3/12/1, HIC Town Hall committee minutes.

81 See chapter 5 .

82 See, for example $H C, 5$ November 1853.

83 Linstrum (1978), p.339; Hordern, 'Notes', 1856, p. 44.

84 DD/RA/C/5, Bateman to Loch, 20 January 1847.

$85 \mathrm{DD} / \mathrm{RA} / \mathrm{C} / 5$, Loch to Mrs Ramsden, 21 January 1847. There was more immediate success in relocating the slaughterhouse from the town centre to Aspley, for similar public health reasons and at Loch's instigation, in 1845. (DD/RA/C/2, Loch to Mrs Ramsden, 29 September 1844).

86 See chapter 4.

87 Buxton (2017), p.53.

88 Buxton's judgement that 'Jack's lifelong approach to business affairs ... showed an uncanny resemblance to that of George Loch' (Buxton (2017), p.61) is thus perhaps a little one-sided.

89 HC, $20 \& 27$ July 1850.

90 KMT18/2/3/12/1, HIC Burial Ground Committee (BGC) minutes, 15 July 1850.

91 Loch to Hathorn, reproduced in BGC, 28 March 1851.

92 DD/RA/C/4/8, Fenton to Ramsden, 27 November 1850. 
93 See chapter 3.

94 DD/RE/C/62, Hathorn to Loch, 27/8/49; Law (1992), p.68, referencing DD/ RE/C/90. See also below, p. 166.

95 KMT18/2/3/12/1, Minutes of the HIC Market Tolls (Special) Committee, 16 June 1852.

96 Law (1992), pp.80-1.

97 I am grateful to Brian Haigh for this point. Interestingly HIC Chair Joseph Brook had noted in $1850 \mathrm{a}$ 'strong desire in the public mind for a recreation ground and public gardens', but argued that a well-done cemetery would meet this (DD/RE/C/79, 12 December 1850).

98 The account of this episode summarises Griffiths (2011c), pp.16-25.

99 HC, 28 August 1858. Springwood Hall was a Georgian mansion of c.1805.

100 DD/RA/11, Nelson to Ramsden, 1 September 1858.

101 HC, 8 January 1859.

102 KMT9/17/1, Draft HIC Park Committee minute, 17 November 1858.

103 DD/RA/C/41/1, 1862.

104 See above, p. 23.

105 Buxton (2017), p.187.

106 These events are detailed in Griffiths (2018).

$107 \mathrm{DD} / \mathrm{RA} / \mathrm{C} / 35 / 10$ - the source for all quotations in this section unless otherwise stated.

108 HC, 14 November 1868, 30 October 1869, 28 October 1893; DD/AH/2. In the 1860s it had become customary for the HIC chair to serve as constable.

109 Ramsden's letter of concession was printed in full in HC, 22 June 1867.

110 The agreement is set out in DD/RE/198.

111 DD/RA/C/26/4, Ramsden to Graham, 1 April 1870.

112 S. Chadwick, HDE, 23 July 1968. For Longley Hall see chapter 1, pp. 27-34.

113 Hordern, 'Notes', 1870, p. 89.

114 See Pearce (2018) for details.

115 KMT18/2/2/1, HIC minute, 3 October 1866; DD/RE/198, Nelson to Ramsden, 5 October 1866, Ramsden to Nelson, 8 October 1866, Nelson to Ramsden, 13 October 1866.

$116 \mathrm{DD} / \mathrm{RA} / \mathrm{C} / 26 / 1,6 / 5 / 69$.

117 This and other details in this paragraph are from a memo by Graham and accompanying bundle of correspondence, in connection with the 1876 Huddersfield Improvement Bill (see below), DD/RA/C/vol III. One design was in Gothic style by W. H. Crossland (DD/RE/49).

118 Cannadine (1980), p.59.

119 See Chapters 6 and 7.

120 DD/RA/C/35/10.

121 Evans (2018), p.91.

122 DD/RA/C/33/14, 7 February 1871, 27 June 1871; DD/RE/198, 31 May 1873

123 HC, 22 February 1871.

124 Wright Mellor was a cloth merchant and a long-term ally of Ramsden and his moderate Liberalism. In 1860 he had been party to manoeuvres by Ramsden to provide covert financial backing to the Examiner, the town's Liberal newspaper [see chapter 3,pp. 103,108]

125 DD/RE/198; DD/RA/C/15/2.

126 DD/RA/1(11), 29 June 1877; DD/RA/15(5). For further details, see Griffiths (2011b). 
127 Huddersfield Weekly News, 4 October 1884.

128 This summary is adapted, with thanks, from unpublished notes by Christopher Marsden, 'Aspects of Victorian St George's Square and Huddersfield' (2013).

129 DD/RA/C/26/4, Ramsden to Tomlinson, 11 May 1870.

130 DD/RA/C/vol III (1876 Act bundle), Ramsden to Graham, 20 July 1872.

131 DD/RA/C/vol III (1876 Act bundle), Graham to Ramsden, 2 \& 3 October 1872; Ramsden to Graham, 10 October 1872.

132 DD/RA/C/vol III (1876 Act bundle), Graham to Ramsden, 2 \& 3 October 1872.

133 The exclusion of Market Place from the list is puzzling. In 1888 a Ramsden-gifted Jubilee fountain was erected there, presumably without interfering with the cross. In 1920 the Corporation resolved to move it to St Paul's Gardens, one of the triangles referred to in section 69; it now stands in Greenhead Park.

134 The creation of the Municipal Offices and Town Hall is related in Haigh (2001).

135 Cooksey (1999), pp.21-2.

136 HC, 31 October 1877, 11 January 1878.

137 See https://huddersfield.exposed/wiki/Chronology of Acts, for the various Acts.

138 DD/RA/C/20/6, 1880; DD/RE/198, 1886-7;DD/RA/C/21/10, 1890; DD/ RA/C/14/3, 1892.

$139 \mathrm{DD} / \mathrm{RA} / \mathrm{C} / 26 / 2,1872 ; H C, 15$ February 1898. Nor had they pursued an offer from Ramsden, also in 1887, to provide a new site for the 60-year old Infirmary if the Corporation would buy the existing two-acre site in New North Rd for the erection of a library, art gallery and public baths (HC, 11 February 1887). The site in question had been owned by the estate until 1848, when Thomas Firth - the obstinate Beast Market freeholder - had bought it for $\mathcal{E} 1,000$ and given it to the Infirmary in order to release them from the estate's rent.

140 DD/RA/C/21/10, 1890.

141 Moore (1976), p. 433.

142 Compiled from various sources, principally DD/RA/C/36, supplemented by deeds and Hordern's 'Notes', 1848, p. 18; 1872, p. 97; 1876, p. 112; 1888, p. 131.

143 Springett (1979), p.16.

144 DD/RA/C, vol III, 19 May 1886.

145 Cannadine (1980), p.406.

146 This was in connection with the sewage works, and in fact Ramsden consented because of the 'urgent necessity' of the case (DD/RA/C/20/6, Graham to Batley, 15 March 1880).

147 Springett (1982), p.141.

148 Trainor (1993), pp. 250-3, identifies a very similar blend in the relationships between Dudley and West Bromwich boroughs, also late to be incorporated, and their former aristocratic 'owners', the earls of Dudley and Dartmouth (the latter also with substantial interests around Huddersfield).

149 Buxton (2017), p.181.

150 DD/RA/2, 1910/11.

151 See chapter 4.

$152 \mathrm{DD} / \mathrm{RA} / \mathrm{C} / 21 / 10$.

153 Pearce (2018), pp.55-6.

154 DD/RA/2,JFR to Beadon, 15 April 1911.

155 DD/RA/2, Plan dated 25 August 1911.

156 Buxton (2017), p. 214. 